\title{
Hydrogen Generation through Solar Photocatalytic Processes: A Review of the Configuration and the Properties of Effective Metal-Based Semiconductor Nanomaterials
}

\author{
Laura Clarizia $^{1}$, Danilo Russo ${ }^{1, *}$, Ilaria Di Somma ${ }^{2}$ (D), Roberto Andreozzi ${ }^{1}$ and \\ Raffaele Marotta ${ }^{1, *}$ (i) \\ 1 Dipartimento di Ingegneria Chimica, dei Materiali e della Produzione Industriale (DICMAPI), \\ ScuolaPolitecnica e delle Scienze di Base, Università di Napoli Federico II, p.le Tecchio, 80, 80125 Napoli, \\ Italy; laura.clarizia2@unina.it (L.C.); randreoz@unina.it (R.A.) \\ 2 Istituto Ricerche sulla Combustione, Centro Nazionale delle Ricerche (IRC-CNR), p.le Tecchio, 80, \\ 80125 Napoli, Italy; idisomma@unina.it \\ * Correspondence: danilo.russo3@unina.it (D.R.); rmarotta@unina.it (R.M.)
}

Received: 6 September 2017; Accepted: 12 October 2017; Published: 17 October 2017

\begin{abstract}
Photocatalytic water splitting and organic reforming based on nano-sized composites are gaining increasing interest due to the possibility of generating hydrogen by employing solar energy with low environmental impact. Although great efforts in developing materials ensuring high specific photoactivity have been recently recorded in the literature survey, the solar-to-hydrogen energy conversion efficiencies are currently still far from meeting the minimum requirements for real solar applications. This review aims at reporting the most significant results recently collected in the field of hydrogen generation through photocatalytic water splitting and organic reforming, with specific focus on metal-based semiconductor nanomaterials (e.g., metal oxides, metal (oxy)nitrides and metal (oxy)sulfides) used as photocatalysts under UVA or visible light irradiation. Recent developments for improving the photoefficiency for hydrogen generation of most used metal-based composites are pointed out. The main synthesis and operating variables affecting photocatalytic water splitting and organic reforming over metal-based nanocomposites are critically evaluated.
\end{abstract}

Keywords: hydrogen; solar fuels; water photosplitting; photoreforming; solar energy; nanotechnology; nanomaterials; heterojunction photocatalysis

\section{Introduction}

Hydrogen is an attractive green energy vector due to its energy content and the lack of greenhouse gas emission after its combustion. At present, the main technologies of hydrogen production involve fossil fuels: hydrogen is mainly produced through steam reforming and water gas shift processes [1]. Further side technologies for its production include chemical, electrochemical, biological and thermal processes [2-4].

The possibility of producing energy by employing solar energy has gained increased interest in the last few years [5]. Especially, thermochemical [6], photoelectrochemical [7-10] and photochemical processes [11,12] can be employed for solar hydrogen generation. Photocatalytic hydrogen generation can be achieved through water photosplitting [13] or photoreforming of organic species [14]. Solar photocatalytic processes for $\mathrm{H}_{2}$ production need catalysts able to absorb radiation in the visible range and efficiently use it to promote electrons to the energy level required for hydrogen formation [15].

Photocatalytic water splitting consists of water decomposition into hydrogen and oxygen by reaction with photogenerated charge carriers. Photocatalytic reforming is based on the ability of 
selected organic species (i.e., sacrificial agents) to be oxidized by photogenerated positive holes and to release protons, which in turn generate hydrogen by reacting with photo-electrons.

\section{Photocatalyst Properties}

\subsection{Thermodynamic and Kinetic Requirements for Water Splitting Reaction}

Water splitting (1) is an endergonic reaction. The change in Gibbs free energy for water dissociation at standard conditions is $237 \mathrm{~kJ} / \mathrm{mol} \mathrm{H}_{2}$.

$$
\mathrm{H}_{2} \mathrm{O}_{(1)} \rightarrow \mathrm{H}_{2}+0.5 \mathrm{O}_{2}
$$

Such a value of Gibbs free energy corresponds to (i) a minimum cell voltage of +1.23 Vrequired to perform water splitting in electrochemical cells and (ii) light radiations with wavelengths shorter than $1100 \mathrm{~nm}$ to employ photochemical processes. Consistently, a minimum band gap of $1.23 \mathrm{eV}$ in semiconductor photocatalysts is required.

However, as water molecules are kinetically stable under irradiation with a wavelength of about $1100 \mathrm{~nm}$, a more stringent kinetic requirement related to the activation energy for $\mathrm{H}-\mathrm{O}$ bond cleavage (500 kJ/mol) occurs. Indeed, a maximum wavelength of $250 \mathrm{~nm}$ (UV-C radiation) [16] is required. Thus, a suitable photocatalyst should (i) possess a band gap higher than $1.23 \mathrm{eV}$ and (ii) be able to promote $\mathrm{H}-\mathrm{O}$ bond cleavage by decreasing the reaction energy barrier (500 kJ/mol) (Figure 1).

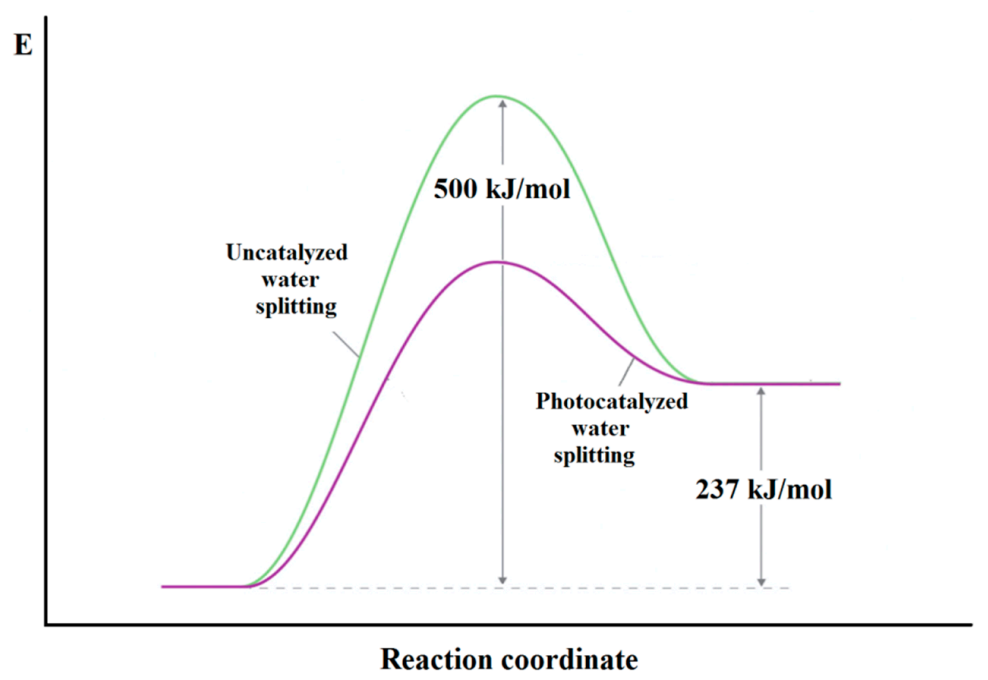

Figure 1. Photocatalytic and non-catalytic energy requirements for water splitting.

\subsection{Hydrogen Generation Efficiency}

The efficiency for hydrogen generation through photocatalytic water splitting can be expressed as $[17,18]$ :

$$
Q E=\frac{\text { Outputenergyas } \mathrm{H}_{2}}{\text { Inputenergy (incidentlight) }} \%=\frac{r_{\mathrm{H}_{2}} \cdot \Delta G_{\mathrm{H}_{2} \mathrm{O}}^{o}}{I \cdot S} \%
$$

where $r_{\mathrm{H}_{2}}\left(\frac{\mathrm{mol}}{\mathrm{s}}\right), \Delta G_{\mathrm{H}_{2} \mathrm{O}}^{o}\left(\frac{\mathrm{J}}{\mathrm{mol}}\right), I\left(\frac{\mathrm{W}}{\mathrm{cm}^{2}}\right)$ and $S\left(\mathrm{~cm}^{2}\right)$ are the hydrogen production rate, the standard Gibbs free energy needed to produce one mole of hydrogen from water $(237 \mathrm{~kJ} / \mathrm{mol})$, the specific power of the light source and the irradiated area, respectively.

In the case of photocatalytic reforming of organics, a different expression of light-to-hydrogen conversion efficiency can be adopted:

$$
Q E=\frac{R_{\mathrm{H}_{2}} \cdot 2 \cdot H_{c o m b}^{o}}{I \cdot S} \%
$$


where $\Delta H_{c o m b}^{o}$ is the standard enthalpy change for the combustion reaction between oxygen and hydrogen $(-282 \mathrm{~kJ} / \mathrm{mol})$. Overall, only a minor fraction of the available papers dealing with photocatalytic hydrogen generation estimated the quantum efficiency $(Q E)$. In most cases, the adopted catalyst load is not taken into account; however, any direct comparison between the photoactivity ( $\mu \mathrm{mol}$ $\left.\mathrm{H}_{2} /\left(\mathrm{s} \cdot \mathrm{g}_{\text {catalyst }}\right)\right)$ of various materials can be drawn due to different operating conditions (i.e., effective specific light source).

An efficient photocatalyst should meet several requirements. First of all, an efficient catalyst should be (i) photo-hydrostable in aqueous solution without undergoing photocorrosion [19] and (ii) easily recoverable from the aqueous mixture at the end of thephotocatalytic process.

Secondly, an efficient photocatalyst should reduce the likelihood of photogenerated electron/hole recombination (reaction time range $10^{-12}-10^{-6} \mathrm{~s}$ ) and promote the migration of photogenerated charge carriers to the surface of the photocatalyst (migration time scale: $10^{-8}-10^{-1} \mathrm{~s}$ ) where they may be involved in the half reactions of interest. The following strategies are widely employed in order to achieve such targets:

- $\quad$ size and shape tuning of the photocatalyst particles (water photosplitting and photoreforming);

- band gap engineering of the photocatalysts (water photosplitting and photoreforming);

- use of suitable sacrificial electron donors (photoreforming).

Thirdly, the band gap value and the energetic levels of the conduction/valence bands in the photocatalyst should be suitable for the occurrence of redox reactions between photogenerated charge carriers and water or organic molecules [20]. In photocatalytic water splitting, after catalyst photoactivation (2), photogenerated holes oxidize $\mathrm{H}_{2} \mathrm{O}$ molecules releasing protons (3), which are reduced to $\mathrm{H}_{2}$ by reacting with photogenerated electrons (4):

$$
\begin{array}{cc}
\text { Semiconductor } \stackrel{\mathrm{h} v}{\rightarrow} \mathrm{e}_{\mathrm{cb}}^{-}+\mathrm{h}_{\mathrm{vb}}^{+} \\
\mathrm{H}_{2} \mathrm{O}+2 \mathrm{~h}_{\mathrm{vb}}^{+} \rightarrow 0.5 \mathrm{O}_{2}+2 \mathrm{H}^{+} & \mathrm{E}_{\mathrm{H}_{2} \mathrm{O} / \mathrm{O}_{2}}=1.23 \mathrm{~V} \\
2 \mathrm{H}^{+}+2 \mathrm{e}_{\mathrm{cb}}^{-} \rightarrow \mathrm{H}_{2} & \mathrm{E}_{\mathrm{H}^{+} / \mathrm{H}_{2}}=0 \mathrm{~V}
\end{array}
$$

The valence band of the photocatalyst should therefore be more positive than the redox potential of $\mathrm{O}_{2(\mathrm{~g})} / \mathrm{H}_{2} \mathrm{O}_{(\mathrm{L})}(1.23 \mathrm{~V}$ vs. NHE at $\mathrm{pH}=0)$, whereas its conduction band has to be more negative than the redox potential of the couple $\mathrm{H}^{+} / \mathrm{H}_{2(\mathrm{~g})}(0 \mathrm{~V}$ vs. $\mathrm{NHE}$ at $\mathrm{pH}=0)$. In addition, an over potential of $-0.41 \mathrm{~V}$ is required for the generation of hydrogen in aqueous solution [21], and consequently, the conduction band of the photocatalyst should be more negative than $-0.41 \mathrm{~V}$.

Therefore, in order to meet such energetic requirements, an efficient photocatalyst should possess a band gap larger than 1.6-1.8 eV. Besides, the band gap should be narrower than about $2.2 \mathrm{eV}$ in order to efficiently activate under natural solar light irradiation (Figure 2).

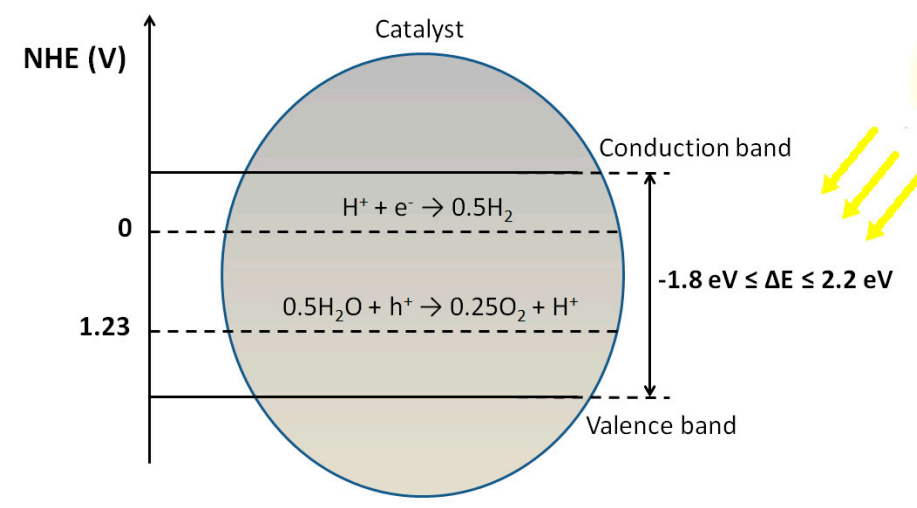

Figure 2. Band potentials and energy gap required for solar-driven photocatalytic water splitting. 
On the other hand, photocatalytic reforming is based on the oxidation of organic sacrificial agents by photogenerated holes forming protons, which are reduced by photogenerated electrons to generate hydrogen gas (Figure 3). In this case, the valence band should be more positive than the redox potential of the sacrificial species.

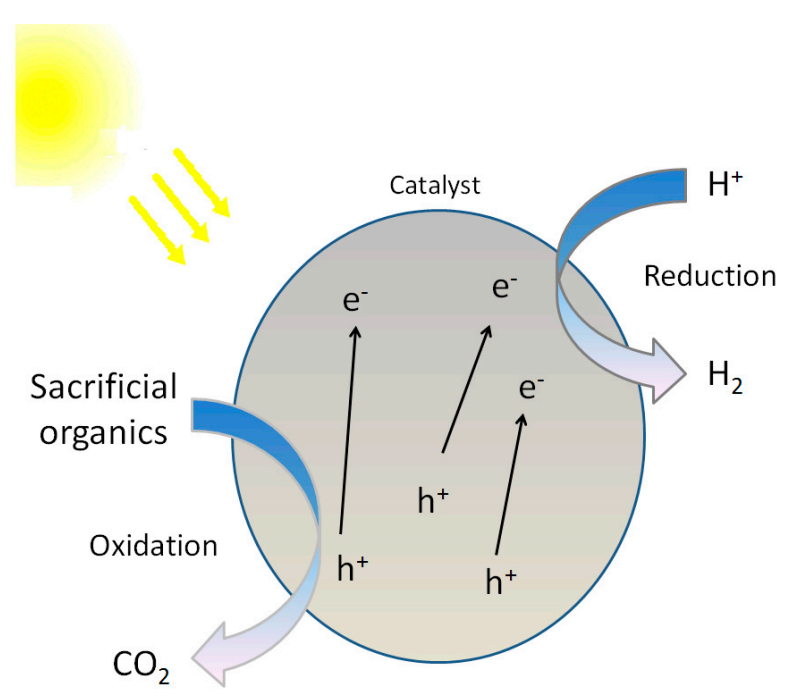

Figure 3. Photocatalytic reforming of organic species.

In accordance with microscopic reversibility, catalysts promote both direct (i.e., water dissociation in photosplitting and organic oxidation in photoreforming) and reverse reactions. In such photocatalytic systems, oxygen competes with protons in photogenerated electron capture, thus impairing hydrogen generation. In order to avoid the presence of oxygen in the reacting mixture and also suppress hydrogen-oxygen recombination reaction, purging the reacting system with an inert gas is an effective strategy.

A number of heterogeneous semiconductors possessing some of the above-mentioned requirements has been so far developed for the photocatalytic hydrogen generation. The most commonly-used metallic elements are mainly in the form of oxides or sulfides [17,22]. It should be observed that such elements are adopted in their highest oxidation state $\left(\mathrm{Ti}^{4+}, \mathrm{Zr}^{4+}, \mathrm{Nb}^{5+}, \mathrm{Ta}^{5+}\right.$, $\left.\mathrm{W}^{6+}, \mathrm{Ce}^{4+}, \mathrm{Ga}^{3+}, \mathrm{In}^{3+}, \mathrm{Ge}^{4+}, \mathrm{Sn}^{4+}, \mathrm{Sb}^{5+}\right)[19]$.

Transition-metal cations with empty $d$ or $f$ orbitals have a $d^{0}$ and $f^{0}$ electronic configuration, respectively, whereas metal cations with filled $d$ orbitals possess a $d^{10}$ electronic configuration.

In order to develop novel visible-light-active photocatalysts with increased quantum efficiency, doping semiconductor materials with selected transition-metal elements, acting as co-catalysts inazero-valent $(\mathrm{Au}, \mathrm{Ag}, \mathrm{Cu}, \mathrm{Pt}$, etc. $)$ or higher oxidation state $\left(\mathrm{Cr}^{3+}, \mathrm{Ni}^{2+}, \mathrm{Rh}^{3+}, \mathrm{Ru}^{+4}\right)$, represents an effective approach.

It is important to note that some metal compounds with a $d^{n}(0<n<10)$ electronic configuration, such as $\mathrm{CdS}$ and $\mathrm{ZnO}$, although expected to exhibit remarkable photoefficiency, are not commonly employed due to their poor photochemical stability in aqueous solution ((5) and (6)) [22]:

$$
\begin{gathered}
\mathrm{CdS} \stackrel{2 \mathrm{~h}^{+}}{\rightarrow} \mathrm{Cd}^{2+}+\mathrm{S} \\
\mathrm{ZnO} \stackrel{2 \mathrm{~h}^{+}}{\rightarrow} \mathrm{Zn}^{2+}+\frac{1}{2} \mathrm{O}_{2}
\end{gathered}
$$

The use of zero-valent metals as co-catalysts on the semiconductor leads to a "metal-semiconductor heterojunction", whereas coupling various semiconductors results in a "semiconductor-semiconductor heterojunction" [23]. 


\section{Configurations of Photocatalytic Materials for Hydrogen Generation}

\subsection{Photocatalytic Water Splitting}

\subsubsection{Metal-Semiconductor Heterojunctions}

Due to its high physicochemical stability in aqueous solution, great availability, low cost and limited toxicity, titanium dioxide is the most widely-used photocatalyst in water splitting processes [24]. However, two major drawbacks limit the use of titanium dioxide in full-scale applications. Firstly, due to its wide band gap $(3.2 \mathrm{eV})$, titanium dioxide requires light irradiation with wavelengths shorter than $387 \mathrm{~nm}$ (UV-A) for its photoactivation. As the UV-A component accounts for only about $5 \%$ of the total solar spectrum at sea level, this aspect constitutes a severe limitation for solar implementations.

Secondly, poor photonic efficiencies due to prompt recombination of photogenerated electron/hole pairs are recorded for water photosplitting over $\mathrm{TiO}_{2}$-based catalysts.

Several metals have been so far employed as cocatalysts in order to (i) extend the light absorption of $\mathrm{TiO}_{2}$ to the visible range of the solar spectrum and (ii) decrease the recombination of photogenerated charge carriers, thus allowing one to achieve higher quantum yield values. For instance, increased photoefficiencies have been recorded when noble metal nanoparticles with a wide work function $\left(\phi_{\mathrm{m}}\right.$, generally larger than $\left.5.0 \mathrm{eV}\right)$, such as $\mathrm{Ag}[25,26], \mathrm{Au}[27], \mathrm{Cu}[28,29], \mathrm{Pt}[30-32]$ and $\mathrm{Pd}[33]$, are deposited on the $\mathrm{TiO}_{2}$ surface. In the cases of $\mathrm{Cu}, \mathrm{Pt}$ and $\mathrm{Pd}$, such a result has been associated with a minor electrons/holes recombination due to the creation of Schottky barriers at the metal/ $\mathrm{TiO}_{2}$ interface [34] (Figure 4). More to the point, electrons move from the conduction band of $\mathrm{TiO}_{2}$ to the metal until the Fermi level $\left(\mathrm{E}_{\mathrm{F}}\right)$ equilibration occurs, as the work functions of selected noble metals $\left(\phi_{\mathrm{m}}\right)$ are higher than titanium dioxide $\left(\phi_{\mathrm{s}}\right)$. As a consequence, the Fermi levels of both the metal and semiconductor turn out to be aligned with the conduction band of titanium dioxide [35]. As a result of this process, excess negative charges and more negative energy levels promote proton ion reduction from a kinetic and thermodynamic point of view, respectively. On the other hand, a Schottky-type potential barrier and excess positive charges occur in the semiconductor. The resulting potential barrier $\left(\mathrm{V}_{\mathrm{D}}\right)$ at the noble metal- $\mathrm{TiO}_{2}$ interface (heterojunction) acts as an active electron trap, thus limiting photogenerated charge carriers' recombination and increasing the photoefficiency for hydrogen generation. Platinum has proven to be one of the most suitable metals to form a Schottky barrier with titanium dioxide, therefore promoting hydrogen production [29].



(a)

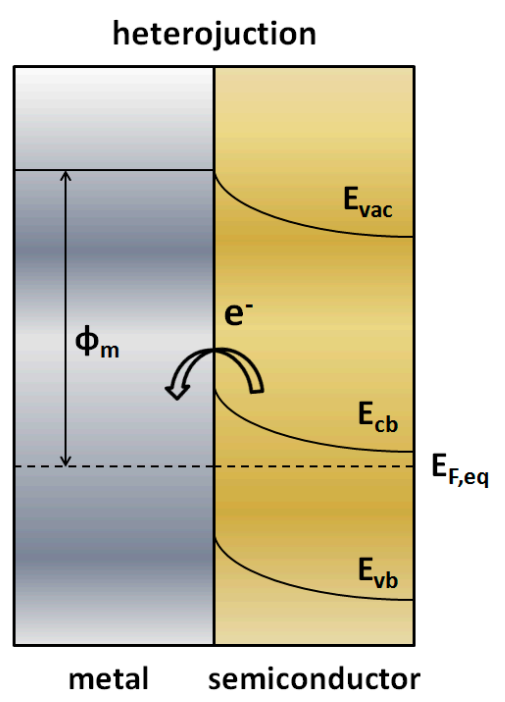

(b)

Figure 4. Metal/semiconductor Schottky junction with energy level equilibration. (a) Before heterojunction; (b) after heterojunction. 
Incorporating nanosized metal particles on titanium dioxide can also lead to an increased photoactivity under visible light irradiation. Such a phenomenon, also known as "Local Surface Plasmonic Resonance" (LSPR) [36,37], occurs when the electromagnetic field has an oscillation frequency in phase with free electrons on the metal [38]. Thus, nanosized metal particles (i) act as antennas by promoting visible light absorption and (ii) sensitize titanium dioxide by favoring the flux of charge carriers on to the conduction band of the semiconductor in the so-called "Process of Plasmon-Induced Resonance Energy Transfer" (PIRET) [39]. In recent years, a great effort has been recorded among researchers in sensitizing the most widely-adopted metal oxides, such as $\mathrm{TiO}_{2}[40,41]$, with the aim of employing the visible light range of natural solar light. Nevertheless, "metal-semiconductor" heterojunctions mostly provide photoactivation under light irradiation with wavelengths shorter than $400 \mathrm{~nm}$. Amongst recently-developed "metal-semiconductor" heterojunctions with a narrow band gap and band edges suitable for water photosplitting, $\mathrm{Pt} / \mathrm{PbBi}_{2} \mathrm{Nb}_{2} \mathrm{O}_{9}$ [42], (V,Rh)/ $\mathrm{SrTiO}_{3}$ [43], (Zn,Rh,Cr)/ $\mathrm{Ga}_{2} \mathrm{O}_{3}$ [41], (La, Rh, Au)/ $\mathrm{SrTiO}_{3}$ [44], $\mathrm{Au} / \mathrm{CeO}_{2}$ [45], $(\mathrm{Mo}, \mathrm{Au}) / \mathrm{BiVO}_{4}$ [46], sulfide-based materials [22], $\mathrm{CoO}$ [47] and cadmium chalcogenides [48] have to be noted.

\subsubsection{Semiconductor-Semiconductor Junctions}

Coupling two semiconductors with the same bandgap yields semiconductor-semiconductor homojunctions. In this respect, $\mathrm{P} 25-\mathrm{TiO}_{2}$ with its crystalline phase composition accounting for $80 \%$ anatase (band gap $3.2 \mathrm{eV}$ ) and $20 \%$ rutile (band gap $3.0 \mathrm{eV}$ ) is a representative case [32].

Compared to pristine anatase or rutile $\mathrm{TiO}_{2}, \mathrm{P}_{2} 5-\mathrm{TiO}_{2}$ exhibits higher photoefficiency attributed to asynergistic effect of the mixed phases enhancing photogenerated electron/hole pairs' separation [49]. As regards the electron flux direction within the $\mathrm{P} 25-\mathrm{TiO}_{2}$ structure (rutile-to-anatase or vice versa), conflicting hypotheses have been found in the literature review [50-53]. Further possible semiconductor-semiconductor homojunctions, such as $\alpha-\mathrm{Ga}_{2} \mathrm{O}_{3} / \beta-\mathrm{Ga}_{2} \mathrm{O}_{3}$ [54] and $\alpha-\mathrm{CaTa}_{2} \mathrm{O}_{6} /$ $\beta-\mathrm{CaTa}_{2} \mathrm{O}_{6}[55]$, are reported.

When materials with different electronic structuresand bandgapscome into contact, such as $n$-type and $p$-type semiconductors, "semiconductor-semiconductor" heterojunctions occur [56]. Based on the relative band energies of the $n$ - and $p$-type semiconductors, three different heterojunction configurations can be identified as follows: the "type-I or straddling gap", the "type-II or staggered gap" and the "type-III or broken gap" [57] (Figure 5).

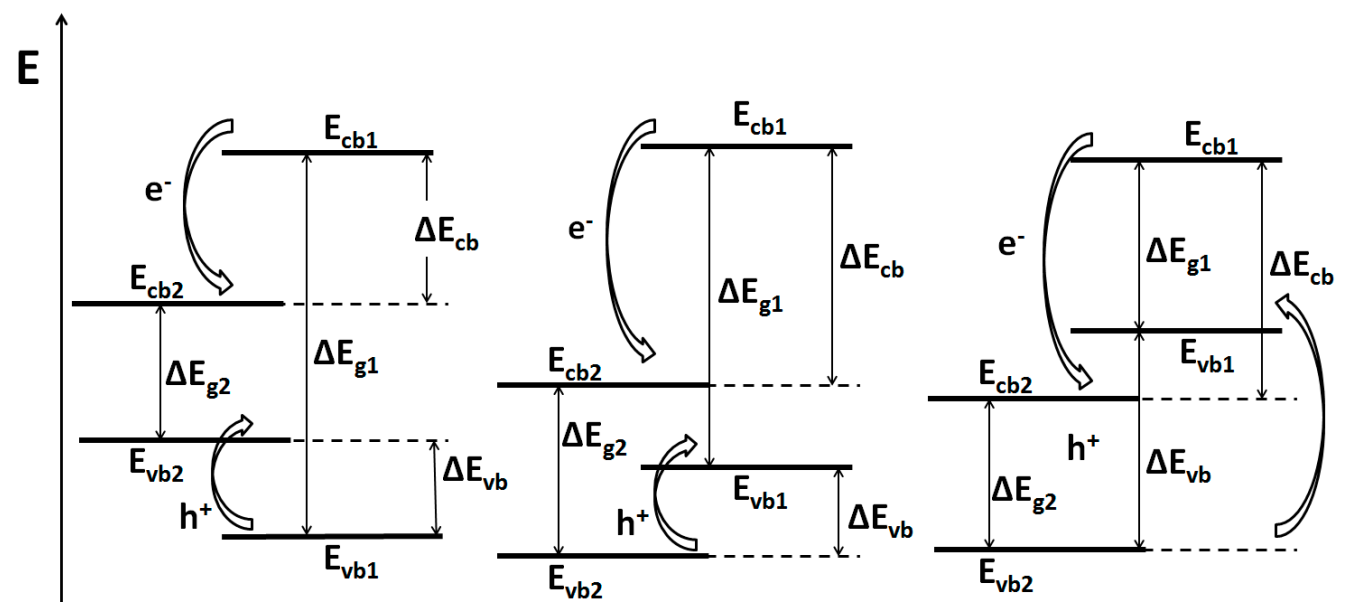

Figure 5. Three possible configurations of $n-p$ heterojunctions.

Type-I (straddling-gap): The band edges of one of the two semiconductors lie wholly within the other ones (i.e., $\Delta \mathrm{E}_{\mathrm{g} 1}>\Delta \mathrm{E}_{\mathrm{g} 2}$ ). Both photogenerated holes and electrons shift from Semiconductor 1 to Semiconductor 2 . 
Type-II (staggered-gap): Band gaps of the two semiconductors intersect. In particular, both band edges of one semiconductor are higher than the other material. Photogenerated holes move from $\mathrm{E}_{\mathrm{vb} 2}$ to $\mathrm{E}_{\mathrm{vb} 1}$, whereas photogenerated electrons flow from $\mathrm{E}_{\mathrm{cb} 1}$ to $\mathrm{E}_{\mathrm{cb} 2}$.

Type-III (broken-gap): No overlap of band gaps occurs. As illustrated in Figure 5, photogenerated charge carriers move as in the case type-II.

As shown in Figure 6, further distinction based on morphology has been made. The following structures can be distinguished: "core/shell" and "Janus type".

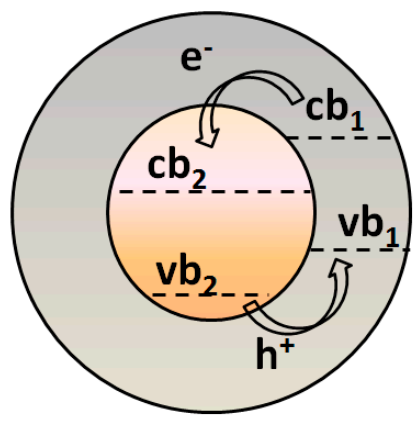

a

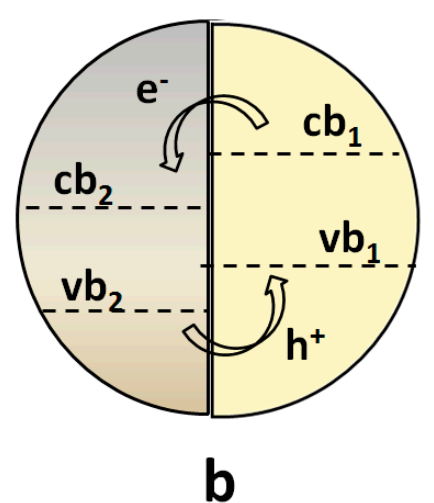

b

Figure 6. Core shell (a) and Janus type (b) structures.

In the case of core/shell structure, an outer semiconductor completely envelops a second material. Only charge carriers available on the external semiconductor are therefore involved in half reactions of interest. On the other hand, in the Janus type structure, both semiconductors are exposed to aqueous solution, thus allowing the respective charge carriers to perform chemical transformations at the surface. Higher likelihood of charge carriers' separation and transfer at the semiconductor-liquid interface is ascribed to the Janus type-II $n-p$ heterostructure. In such a case, charge carriers with increased lifetime can undergo redox reactions and enhance hydrogen generation [58]. Several metal-based nanoparticles with $n-p$ heterojunctions have been recently developed for different photocatalytic applications [59-64]. Some of those that have been successfully employed for solar-driven hydrogen generation through water photosplitting are reported in Table $1[29,58,65]$.

Table 1. Selected photocatalytic systems recently developed for water photosplitting under UV-A $(\lambda>300 \mathrm{~nm})$ and visible light $(\lambda>400 \mathrm{~nm})$ irradiation.

\begin{tabular}{cccc}
\hline Photocatalyst & Band Gap (eV) & Wavelength (nm) & Ref. \\
\hline $\mathrm{TiO}_{2}$ (anatase)- $\mathrm{TiO}_{2}($ rutile) & 2.78 & $\lambda>300$ & {$[50,66]$} \\
\hline Tantalates-NiO & $3.6-4.0$ & $\lambda>310$ & {$[67]$} \\
\hline Perovskites-NiOx & $3.2-4.7$ & $\lambda<350$ & {$[22]$} \\
\hline Noble metal/ $\mathrm{TiO}_{2}-\mathrm{CdS}$ & $\mathrm{N} / \mathrm{A}$ & $\lambda>400$ & {$[68]$} \\
\hline$\left(\mathrm{Ga}_{0.88} \mathrm{Zn}_{0.12}\right)\left(\mathrm{N}_{0.88} \mathrm{O}_{0.12}\right)-\mathrm{Rh}_{2-\mathrm{x}} \mathrm{Cr}_{\mathrm{x}} \mathrm{O}_{3}$ & 2.6 & $\lambda>400$ & {$[22]$} \\
\hline $\mathrm{Cu}_{1.94} \mathrm{~S}-\mathrm{Zn}_{\mathrm{x}} \mathrm{Cd}{ }_{1-\mathrm{x}} \mathrm{S}(0 \leq \mathrm{x} \leq 1)$ & $2.57-3.88$ & $\lambda>420$ & {$[69]$} \\
\hline $\mathrm{CdS}-\mathrm{ZnS}$ & $\mathrm{N} / \mathrm{A}$ & $\lambda>420$ & {$[70]$} \\
\hline $\mathrm{CdSe} / \mathrm{CdS}-\mathrm{MoS}_{3}$ & $1.75-2.44$ & 450 & {$[71,72]$} \\
\hline $\mathrm{MoS}_{2} / \mathrm{CuInS}{ }_{2}$ & $\mathrm{~N} / \mathrm{A}$ & $\lambda>420$ & {$[73]$} \\
\hline $\mathrm{Cu}_{2} \mathrm{O} / \mathrm{CuO}$ & $1.54-2.01$ & $\lambda>400$ & {$[74]$} \\
\hline $\mathrm{Ni}_{3} \mathrm{~N} / \mathrm{CdS}$ & 2.54 & $\lambda>420$ & {$[75]$} \\
\hline $\mathrm{BaZrO}_{3} / \mathrm{BaTaO}$ & $\lambda>420$ & {$[76]$} \\
\hline
\end{tabular}


Table 1. Cont.

\begin{tabular}{|c|c|c|c|}
\hline Photocatalyst & Band Gap (eV) & Wavelength (nm) & Ref. \\
\hline $\mathrm{Ir} / \mathrm{CoO}_{\mathrm{x}} / \mathrm{Ta}_{3} \mathrm{~N}_{5}-\mathrm{Rh}, \mathrm{Ru} / \mathrm{SrTiO}_{3}$ & $\sim 2.1$ & $\lambda>420$ & [77] \\
\hline $\begin{array}{c}\mathrm{Pt} / \mathrm{BaZrO}_{3}-\mathrm{BaTaO}_{2} \mathrm{~N} \\
\mathrm{TaO}_{\mathrm{x}} \mathrm{N} \text { : Tantalum oxynitride }\end{array}$ & $1.8-1.9$ & $\lambda>420$ & [78] \\
\hline $\mathrm{Ru}, \mathrm{Rh} / \mathrm{SrTiO}_{3}-\mathrm{BiVO}_{4}$ & $\mathrm{~N} / \mathrm{A}$ & $\lambda>420$ & [79] \\
\hline $\mathrm{WO}_{3} / \mathrm{BiVO}_{4}$ & $\sim 2.4$ & $\lambda>420$ & [80] \\
\hline $\begin{array}{c}\mathrm{CdS}-\mathrm{ZnO} / \mathrm{RGO} \\
\text { RGO: reduced graphene oxide }\end{array}$ & $\mathrm{N} / \mathrm{A}$ & $\lambda>400$ & [81] \\
\hline CdS-TaON/RGO & $2.4-2.5$ & $\lambda>420$ & [82] \\
\hline Sulfide based semiconductors & $2.0-2.3$ & $\lambda>420$ & [22] \\
\hline
\end{tabular}

Exhaustive overviews of the heterostructures for water photosplitting have been produced from the literature review $[83,84]$. Bandgap values for many semiconductors have been listed by Luque and Balu [85].

Under UV light irradiation, $\mathrm{Na}, \mathrm{SrTiO}_{3}-\mathrm{Rh}_{\mathrm{x}} \mathrm{Cr}_{2-\mathrm{x}} \mathrm{O}_{3}\left(>2.2 \times 10^{4} \mu\right.$ moles $\mathrm{H}_{2} / \mathrm{h} \cdot \mathrm{g}$ [86]), NiO-NaTaO ( $>2.9 \times 10^{4} \mu$ moles $\mathrm{H}_{2} / \mathrm{h} \cdot \mathrm{g}$ [83]) and Pt-decorated $\mathrm{Cu}_{1.94} \mathrm{~S}_{-} \mathrm{Zn}_{0.23} \mathrm{Cd}_{0.77} \mathrm{~S}\left(>1.3 \times 10^{4} \mu\right.$ moles $\mathrm{H}_{2} / \mathrm{h} \cdot \mathrm{g}$ [69]) exhibit the highest specific rates of hydrogen generation. On the other hand, $\mathrm{ZnFe}_{2} \mathrm{O}_{4}-\mathrm{SrTiO}_{3}$ (>4.0 $\times 10^{5} \mu$ moles $\mathrm{H}_{2} / \mathrm{h} \cdot \mathrm{g}$ [87]), ZnS-In $\mathrm{S}_{3}$-CuS $\left(3.6 \times 10^{5} \mu\right.$ moles $\mathrm{H}_{2} / \mathrm{h} \cdot \mathrm{g}$ [88] $)$ and CdS/ZnS $\left(2.4 \times 10^{5} \mu\right.$ moles $\mathrm{H}_{2} / \mathrm{h} \cdot \mathrm{g}$ [70]) allow one to obtain the best specific productivities under visible light irradiation. However, the comparison between the specific rates of hydrogen generation, reported above, does not take into account the different effective specific light source used in the experimental runs.

Despite $n-p$ heterostructures helping to enhance charge carriers' lifetime, water photosplitting efficiency is still undermined by photogenerated electron/hole recombination. In order to curtail such a phenomenon and eventually avoid photocorrosion of metal sulfides used as semiconductors, the adoption of selected inorganic ions acting as redox mediators [22], such as $\mathrm{Ce}^{4+} / \mathrm{Ce}^{3+}[89]$, $\mathrm{S}^{2-} / \mathrm{SO}_{3}^{2-}[90]$ and $\mathrm{IO}_{3}^{-} / \mathrm{I}^{-}[91]$, is an effective approach. Indeed, such ions offer a two-fold advantage. On the one hand, low oxidation state species react with holes photogenerated in one of the two semiconductors, thus allowing photogenerated electrons to reduce protons and generate hydrogen. On the other hand, high oxidation state species capture electrons photogenerated in the second semiconductor, whereas photogenerated holes oxidize water, releasing oxygen [92].

Photocatalytic systems involving selected redox mediators in the presence of multiple $n$ - and p-type semiconductors are also known as "Z-schemes". As shown in Figure 7, the Z-scheme configuration allows a more efficient use of solar light irradiation due to lower energy required for water dissociation.

Besides traditional metal oxide-based photocatalysts, several new complex nanocomposites based on nitrides, oxynitrides, metal sulfides, metal oxysulfides and tantalates have been studied [93]. Photocatalytic water splitting can be also achieved by coupling catalysts for oxygen (i.e., $\mathrm{BiVO}_{4}$ ) and hydrogen (i.e., doped $\mathrm{SrTiO}_{3}$ ) production [94].

Metal co-catalysts may sometimes lower the photoefficiency of such systems, as the formation of charge trapping sites inhibits the transfer of photogenerated electrons and holes to the surface [22].

Overall, amongst the highest photoefficiency for hydrogen generation so far recorded, the quantum yield values reported by Kim et al. (50\%, alkaline pure water, UV light [95]) over Ba-doped $\mathrm{Sr}_{2} \mathrm{Nb}_{2} \mathrm{O}_{7}$ and Kato et al. (56\%, pure water UV light [96]) over $\mathrm{NiO} / \mathrm{NaTaO}_{3}$ should be noted. However, such efficiencies were recorded under UV light irradiation and have limited significance for solar implementations. The highest quantum yields recorded under visible light irradiation (e.g., <3\%) are still far from reaching the benchmark value ( $>10 \%)$ suggested for real applications [97,98]. 


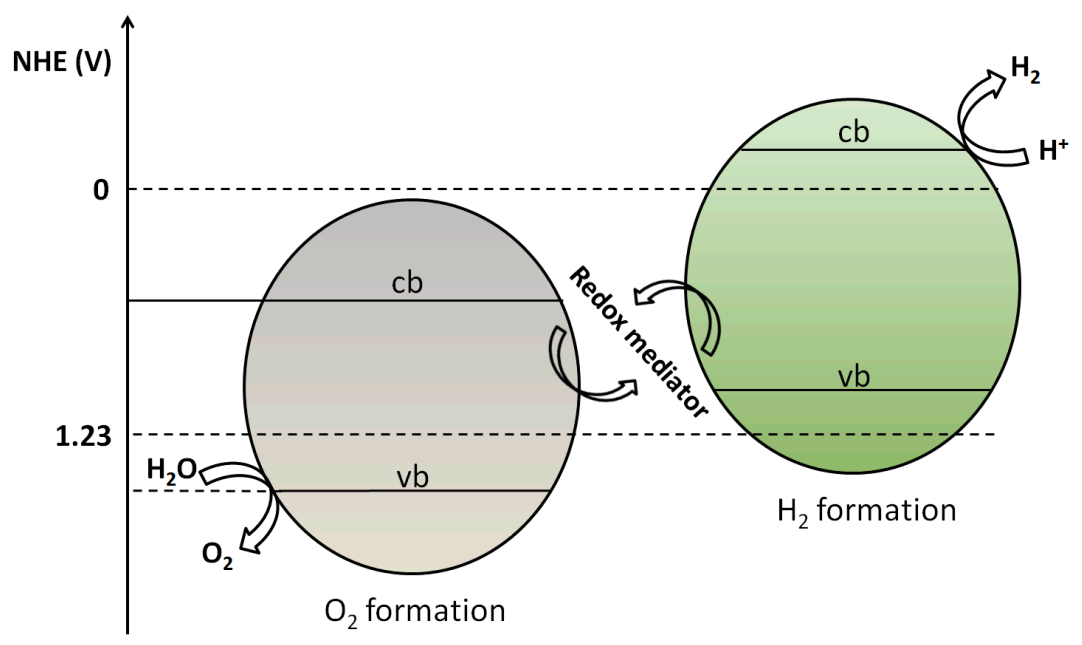

Figure 7. Schematic illustration of the Z-scheme.

\subsection{Photocatalytic Reforming of Organics}

\subsubsection{General Remarks}

Straddling water photosplitting and organic photo-oxidation [99], photocatalytic reforming usually employs short chain alcohols (i.e., methanol, ethanol and glycerol), carboxylic acids (i.e., formic acid and oxalic acid) and carbohydrates (i.e., glucose) or biomass-derived substrates $[14,100,101]$ as sacrificial organic species. As biomass-derived species may be often found in paper and food industry effluents $[102,103]$, photoreforming may be regarded as an outstanding approach combining wastewater treatment and the generation of a high added value energy carrier.

\subsubsection{Reaction Mechanism}

In photocatalytic reforming of organics, photogenerated holes oxidize sacrificial agents releasing protons, which are reduced to hydrogen by photogenerated electrons. In such a case, no oxygen gas is produced, thus enhancing overall process efficiency.

Alcoholic molecules are usually adsorbed on the photocatalyst surface in the non-dissociated form or by creating alkoxy species [104,105].

Higher hydrogen production rates are reported in the literature review with increasing the amount of $\mathrm{OH}$ groups of the organic molecule: polyols (i.e., glucose and glycerol) exhibit remarkable photoefficiency for hydrogen generation [106]. Such a phenomenon has been related to the ability of hydroxyl groups to enhance substrate adsorption on active sites of the photocatalyst. A possible reaction mechanism of alcohols photoreforming is reported in Reactions (7) and (8).

$$
\begin{gathered}
\mathrm{R}-\mathrm{CH}_{2} \mathrm{OH} \stackrel{\mathrm{h}^{+}}{\rightarrow} \mathrm{R}-\dot{\mathrm{C}} \mathrm{HOH}+\mathrm{H}^{+} \\
\mathrm{R}-\dot{\mathrm{C}} \mathrm{HOH} \stackrel{\mathrm{h}^{+}}{\rightarrow} \mathrm{R}-\mathrm{CHO}+\mathrm{H}^{+}
\end{gathered}
$$

Photogenerated holes oxidize the organic species via alfa-hydrogenabstraction, thus generating a $\mathrm{RCH} \cdot \mathrm{OH}$ radical (7), which is further oxidized to aldehyde (8) [107]. Moreover, carboxylic acids can be formed through oxidation of hydrated aldehydes.

The oxidation of long chain alcoholic molecules leads to the formation of hydrogen and carbon dioxide, as well as alkanes as undesired by-products. On the other hand, short chain carboxylic acids (i.e., formic acid) and dicarboxylic acids (i.e., oxalic acid) are promptly mineralized to water and carbon dioxide ((9) and (10)). Subsequently, protons derived from the oxidation process (9) react with photogenerated electrons, thus generating hydrogen gas. 


$$
\begin{gathered}
\mathrm{R}-\mathrm{COOH} \stackrel{\mathrm{h}^{+}}{\rightarrow} \mathrm{R}-\mathrm{COO}+\mathrm{H}^{+} \\
\mathrm{R}-\mathrm{COO} \rightarrow \mathrm{CO}_{2}+\mathrm{R}^{.}
\end{gathered}
$$

As regards photoreforming of carbohydrates, a lack of clarity has been recorded so far about the reaction mechanism. The reaction pathway of glucose oxidation has been investigated by several authors [108,109]. Further efforts in elucidating glucose oxidation were made by Balducci [110], according to whom it proceeds via bridge adsorption on the photocatalyst surface through hydroxyl groups.

Photocatalytic reforming of further organic molecules, such as aldehydes [111,112], carboxylic acids [113,114], cellulose [115] and azodyes [116], has been also reported in the literature review. An extensive classification of organic compounds that could be used as sacrificial agents has been recently drawn up [14].

\subsubsection{Materials}

Heterojunction-based nanosized photocatalysts have been widely investigated in the literature review for photoreforming of several organic compounds $[14,22,29,48]$. Different preparation methods were adopted by researchers, such as the sol-gel method, photodeposition, photoelectrochemical deposition, wet impregnation, thermal, solvothermal and hydrothermal methods, precipitation, chemical vapor deposition, etc. $[28,83]$.

Despite their high cost, noble metals are extensively employed as co-catalysts in photocatalytic reforming. In particular, the highest photoefficiencies for hydrogen production have been achieved in the presence of platinum, followed by palladium and gold $[117,118]$. An effective and low-cost substitute for noble metals is represented by a selected group of Earth-abundant metals including cobalt [119], nickel [120] and copper. In particular, remarkable photoefficiencies were achieved over copper-based metal oxides tested for photocatalytic reforming of several sacrificial organic species $[18,121]$ and in the presence of aqueous matrix with excess chloride ion [122] and nitrate ion [123].

Under equal testing conditions, photoreforming of organics leads to hydrogen generation rates more than two orders of magnitude higher than photocatalytic water splitting [124]. In this respect, some of the most relevant results collected in the literature review are reported in Table 2. At present, the most effective photocatalysts for photoreforming under visible light irradiation are CdS-based materials [125].

Table 2. Selected relevant hydrogen production rates recorded during photoreforming of organics over

\begin{tabular}{|c|c|c|c|c|}
\hline$r_{\mathrm{H}_{2}}\left(\mu\right.$ moles $\left.\mathrm{H}_{2} / \mathrm{h} \cdot \mathrm{g}\right)$ & Material & Sacrificial Agent & Irradiation Type & Reference \\
\hline$>4.3 \times 10^{4}$ & metal/niobates & methanol & UV-A & [126] \\
\hline $1.1 \times 10^{4}$ & $\mathrm{Sr} /$ tantalates & methanol & UV-A & [127] \\
\hline $6.3 \times 10^{4}$ & $\mathrm{Ni} / \mathrm{CdSnanorods}$ & ethanol & visible light & [128] \\
\hline $5.6 \times 10^{4}$ & CdS/RGO & lactic acid & visible light & [129] \\
\hline $4.0 \times 10^{4}$ & $\mathrm{Pt} / \mathrm{CdSe}-\mathrm{CdS}$ & isopropanol & visible light & [130] \\
\hline$>3.7 \times 10^{4}$ & $\begin{array}{l}\mathrm{N} / \mathrm{Zn}, \mathrm{Ga}-\mathrm{mixed} \\
\text { oxide- } \mathrm{Rh} / \mathrm{Cr}_{2} \mathrm{O}_{3}\end{array}$ & methanol & visible light & [131] \\
\hline
\end{tabular}
various materials.

\section{Operating Conditions Affecting Photocatalytic Hydrogen Generation}

Photocatalytic hydrogen production through water splitting or reforming of organics may be substantially affected by the following operating variables: particle size, shape, morphology, structure and crystallinity; band gap energy; co-catalyst nature and preparation method; type and concentration of sacrificial agent; $\mathrm{pH}$ of the solution; presence of oxygen; operating temperature $[13,17,132]$. 


\subsection{Particle Size}

Particle size is a key aspect of effective photocatalytic materials, as it mainly affects bandgap [133,134] and surface area [17]. Secondly, the occurrence of bulk recombination between photogenerated charge carriers is promoted in large-sized particles. The optimal particle size, depending on the composition and structure of the photocatalyst, is about $10 \mathrm{~nm}$ for pure $\mathrm{TiO}_{2}$ [135].

The number of inner surface defects is also proportional to particle size. Large particles may be described as multi-aggregates of ideal crystals with different two- or three-dimensional structures [136]. On the other hand, small particles exhibit broad sections of highly crystalline phases. Nanosized particles consist of an ideal single crystalline particle with finite size.

\subsection{Structure and Morphology}

The structure and morphology of the photocatalyst strongly depend on the preparation method adopted. Temperature and reagents employed for the synthesis define particle size, shape, morphology and crystallinity. Eventual calcination phases after synthesis may also affect surface area and crystallinity. Theoretically, significant increases in photocatalyst stability and crystallinity are amongst the primary targets of an effective calcination. However, in practice, beyond an optimum calcination temperature, lower photoefficiencies due to agglomeration and sintering damage decreasing surface area, leading to phase transition (i.e., anatase to rutile in the case of titanium dioxide), are reported [137].

As regards the electronic properties of such materials, it is important to stress that the nature of the crystallographic phase may influence the bandgap value [134]. Furthermore, structural defects in the photocatalyst bulk can create localized electronic states acting as traps for photogenerated charge carriers [22,138], thus impairing the photoefficiency for hydrogen generation.

\subsection{Surface}

The influence of the specific surface pattern of photocatalysts on the hydrogen generation is quite controversial. A high specific area would increase not only the number of active catalytic sites, but also the number of superficial defect sites, which promote the recombination of free charge carriers [139]. For example, it has been reported that a high surface area for metal chalcogenides promotes the recombination processes through a "non-radiative" decay [140]. On the contrary, other studies demonstrated that an increase in the surface area of nanostructured titania does not generate an enhancement of the recombination rate of photogenerated charges [141].

Large specific surfaces of nanostructured materials also reduce the reflection losses and increase the radiation scattering. In some cases, the efficiency of the photocatalyst can be enhanced with particular chemical treatments [142]. For example, fluoride ions can adsorb on $\mathrm{TiO}_{2}$ substituting the surface hydroxyl groups, and consequently, the number of surface hole traps is decreased [5]. It has been reported that a chlorine passivation decreases the electron trap surface states in CdSe nanocrystals for photocatalytic hydrogen generation, measuring an increase of photoluminescence quantum yield (from $9-22 \%$ after the $\mathrm{Cl}$ treatment) [143].

The deposition of selected noble metals on the surface of the photocatalyst also decreases the electron-hole pair recombination. However, a high load of noble metal atoms favors the formation of surface metal clusters, which act as recombination centers [144].

From a theoretical point of view, some efforts using computational chemistry calculations have been made for the analysis and optimization of the surface design of suitable heterogeneous photocatalysts in order to increase the rate of hydrogen production $[145,146]$. However, new insights in computational modeling of active materials for water photosplitting have been recently reviewed $[65,147,148]$. 


\subsection{Co-Catalyst}

The amount and loading method of co-catalyst are crucial operating variables affecting hydrogen production. Co-catalyst nanoparticles with a uniform distribution can increase hydrogen production rate. However, excess loading may hinder radiation absorption and, in some cases, promote photogenerated electron/hole recombination [149], thus lowering process photoefficiency. An optimumco-catalyst load should be therefore identified. The same goes for the overall catalyst load, for which, after a threshold value depending on the case, hydrogen production stops increasing due to particle agglomeration and radiation shadowing phenomena in highly turbid suspensions [150].

\section{5. $p H$ of the Solution}

The $\mathrm{pH}$ of the solution may significantly impact both the photocatalytic process and photocatalyst stability. Variation in $\mathrm{pH}$ may also influence the band edge position in semiconductor photocatalysts [151,152].

The photocatalyst surface changes its charge status at varying $\mathrm{pH}$ values of the solution depending on the $\mathrm{pH}$ of the zero point of charge $\left(\mathrm{pH}_{\mathrm{zpc}}\right)$ of the semiconductor. If the surface is made of amphoteric groups, as in the case of $\mathrm{TiO}_{2}$, the following equilibria (11)-(12) should be considered [153], where $>\mathrm{OH}_{2}{ }^{+},>\mathrm{OH}$ and $>\mathrm{O}^{-}$are the positive, neutral and negative surface hydroxyl groups, respectively:

$$
\begin{gathered}
>\mathrm{OH}+\mathrm{H}^{+} \stackrel{p K_{a 1}}{\Leftrightarrow}>\mathrm{OH}_{2}{ }^{+} \\
>\mathrm{OH}+\mathrm{OH}^{-} \stackrel{p K_{\beta 2}}{\Leftrightarrow}>\mathrm{O}^{-}+\mathrm{H}_{2} \mathrm{O}
\end{gathered}
$$

The zero point of charge can be estimated through the following Equation (13):

$$
\mathrm{pH}_{\mathrm{zpc}}=\frac{1}{2}\left(p K_{a 1}+p K_{a 2}\right)
$$

When $\mathrm{pH}<\mathrm{pH}_{\mathrm{zpc}}$, the photocatalyst has a positively charged surface. If $\mathrm{pH}>\mathrm{pH}_{\mathrm{zpc}}$, negative charges prevail. Finally, neutral conditions stand for $\mathrm{pH}$ of the solution equal to $\mathrm{pH}_{\mathrm{zpc}}$. Extensive surveys reporting the $\mathrm{pH}_{\mathrm{zpc}}$ values for most used metal oxides and other semiconductors can be found in the literature review $[154,155]$.

As regards water photosplitting, hydrogen generation is promoted under acidic conditions over $\mathrm{RuO}_{2}$-loaded oxynitrides [156,157] and in alkaline conditions by using $\mathrm{NiO}_{\mathrm{x}}$-loaded perovskites $[158,159]$. Even for the same base photocatalyst, the optimal $\mathrm{pH}$ depends on the co-catalyst due to hydrolysis and corrosion phenomena [156,160].

Changes in charge of the solid surface may affect electrostatic interactions between photocatalyst and reagents (i.e., sacrificial agents, redox mediators) [161]. In the case of photoreforming, hydroxyl groups on the surface act as adsorption centers for sacrificial agents and scavenging sites for photogenerated holes [162]. It is reported that hydrogen production increases with increasing concentration of sacrificial agents [163], although very high concentrations of organics result in being detrimental for hydrogen generation as the adsorption sites of the photocatalyst are saturated $[16,164]$.

\subsection{Operating Temperature}

The effect of temperature on photocatalytic processes has to be taken into account due to different activation energy values for each physico-chemical step involved.

Moderate increases in operating temperature enhance the hydrogen production rate $[134,165,166]$. Indeed, high temperatures promote charge carrier mobility, thus reducing the occurrence of photogenerated electron/hole recombination [13]. 


\section{Conclusions}

Photocatalytic hydrogen generation through water photosplitting or organic photoreforming isgaining increasing interest due to the possibility of producing an energy carrier through clean and sustainable processes based on solar energy.

As emerged in the literature survey, despite significant efforts having been made in developing effective metal-based materials for hydrogen generation, the photoefficiency of such composites is still far from satisfying the minimum requirements for commercial applications. Indeed, no metal-based semiconductors suitable to perform photocatalytic water splitting or organic reforming under visible light with photonic efficiency higher than the threshold value suggested for practical applications $(>10 \%$ at $600 \mathrm{~nm})$ have so far been found. Recent literature findings still indicate low efficiencies for visible-light-to-hydrogen conversion $(<3.0 \%)$ for water photosplitting.

Overall, effective photocatalytic composites for visible light water splitting and organic reforming should possess the following features:

- proper band gap energy and band potentials,

- photostability in aqueous solution;

- high crystallinity;

- $\quad$ high specific photoactivity $\left(>10^{4} \mu\right.$ moles $\left.\mathrm{H}_{2} / \mathrm{h} \cdot \mathrm{g}\right)$.

In particular, a band gap larger than $1.6 \mathrm{eV}$ and narrower than $2.2 \mathrm{eV}$ is required in order to allow hydrogen generation through photocatalytic water splitting and to activate under natural solar light irradiation, respectively. Specifically, promising results were obtained for $\mathrm{BaZrO}_{3} / \mathrm{BaTaO}_{2} \mathrm{~N}$, tantalum oxynitrides and copper oxides with band gaps shorter than $2 \mathrm{eV}$. Further efforts should be made adopting such materials by taking into account the relative positions of energy bands and redox potentials of the involved species.

At present, the most effective results under visible light irradiation were obtained forNi/CdS nanorods and CdS/RGO with specific rates of hydrogen generation of about $6 \times 10^{4} \mu \mathrm{mol} / \mathrm{h} \cdot \mathrm{g}$. Interesting photoactivities higher than $4 \times 10^{4} \mathrm{\mu mol} / \mathrm{h} \cdot \mathrm{g}$ were recorded over metal/niobates under UV-A irradiation. In general, the few reported data on light-to-hydrogen energy conversion efficiency are difficult to compare due to different adopted light source powers.

As emerged in the literature survey, no metal-based semiconductors suitable to perform photocatalytic water splitting or organic reforming under visible light with photonic efficiency higher than the threshold value suggested for practical applications $(>10 \%$ at $600 \mathrm{~nm})$ have so far been found. Recent literature findings still indicate low efficiencies for visible-light-to-hydrogen conversion $(<3.0 \%)$ for water photosplitting. A key challenge for future advances in hydrogen generation efficiency could rely on the combination of materials engineering with the design of proper reactor configurations. In particular, the adoption of specific solar collectors could allow employing the beneficial effect of higher operating temperatures on hydrogen evolution.

Moreover, with the aim of implementing photocatalytic hydrogen production in real applications, cost reduction and toxicity assessment of the photocatalytic composites should be also considered.

Conflicts of Interest: The authors declare no conflict of interest.

\section{References}

1. Ullmann's Encyclopedia of Industrial Chemistry; Wiley-VCH Verlag: Weinheim, Germany, 2016.

2. Kothari, R.; Buddhi, D.; Sawhney, R.L. Comparison of environmental and economic aspects of various hydrogen production methods. Renew. Sustain. Energy Rev. 2008, 12, 553-563. [CrossRef]

3. Holladay, J.D.; Hu, J.; King, D.L.; Wang, Y. An overview of hydrogen production technologies. Catal. Today 2009, 139, 244-260. [CrossRef]

4. Molino, A.; Chianese, S.; Musmarra, D. Biomass gasification technology: The state of the art overview. J. Energy Chem. 2016, 25, 20-25. [CrossRef] 
5. Centi, G.; Van Santen, R.A. Catalysis for Renewables: From Feedstock to Energy Production; Wiley-VCH Verlag: Weinheim, Germany, 2008.

6. Steinfeld, A. Solar thermochemical production of hydrogen-A review. Sol. Energy 2005, 78, 603-615. [CrossRef]

7. Kuang, Y.; Jia, Q.; Ma, G; Hisatomi, T; Minegishi, T.; Nishiyama, H.; Nakabayashi, M.; Shibata, N.; Yamada, T.; Kudo, A.; et al. Ultrastable low-bias water splitting photoanodes via photocorrosion inhibition and in situ catalyst regeneration. Nat. Energy 2017, 2, 16191. [CrossRef]

8. Crespo-Quesada, M.; Reisner, E. Emerging approaches to stabilise photocorrodible electrodes and catalysts for solar fuel applications. Energy Environ. Sci. 2017, 10, 1116-1127. [CrossRef]

9. Xu, P.; McCool, N.S.; Mallouk, T.E. Water splitting dye-sensitized solar cells. Nano Today 2017, 14, 42-58. [CrossRef]

10. Kamat, P.V.; Bisquert, J. Solar fuels. Photocatalytic hydrogen generation. J. Phys. Chem. C 2013, 117, 14873-14875. [CrossRef]

11. Zhang, T.; Lin, W. Metal-organic frameworks for artificial photosynthesis and photocatalysis. Chem. Soc. Rev. 2017, 43, 5982-5993. [CrossRef] [PubMed]

12. Wang, Z.; Roberts, Z.Z.; Naterer, G.F.; Gabriel, K.S. Comparison of thermochemical, electrolytic, photoelectrolytic and photochemical solar-to-hydrogen production technologies. Int. J. Hydrogen Energy 2012, 37, 16287-16301. [CrossRef]

13. Ahmad, H.; Kamarudin, S.K.; Minggu, L.J.; Kassim, M. Hydrogen from photo-catalytic water splitting process: A review. Renew. Sustain. Energy Rev. 2015, 43, 599-610. [CrossRef]

14. Puga, A.V. Photocatalytic production of hydrogen from biomass-derived feedstocks. Coord. Chem. Rev. 2016, 315, 1-66. [CrossRef]

15. Hisatomi, T.; Domen, K. Introductory lecture: Sunlight-driven water splitting and carbon dioxide reduction by heterogeneous semiconductor systems as key processes in artificial photosynthesis. Faraday Discuss. 2017, 198, 11-35. [CrossRef] [PubMed]

16. Bowker, M. Sustainable hydrogen production by the application of ambient temperature photocatalysis. Green Chem. 2011, 13, 2235-2246. [CrossRef]

17. Maeda, K. Photocatalytic water splitting using semiconductor particles: History and recent developments. J. Photochem. Photobiol. C Photochem. Rev. 2011, 12, 237-268. [CrossRef]

18. Qureshi, M.; Takanabe, K. Insights on measuring and reporting heterogeneous photocatalysis: Efficiency definitions and setup examples. Chem. Mater. 2016, 29, 158-167. [CrossRef]

19. Kitano, M.; Hara, M. Heterogeneous photocatalytic cleavage of water. J. Mater. Chem. 2010, 20, 627-641. [CrossRef]

20. Khodadadian, F.; Nasalevich, M.; Kapteijn, F.; Stankiewicz, A.I.; Lakerveld, R.; Gascon, J. Photocatalysis: Past Achievements and Future Trends. In Alternative Energy Sources for Green Chemistry; Stefanidis, G., Stankiewicz, A., Eds.; Royal Society of Chemistry: London, UK, 2016.

21. Kumar, P.; Kumar, A.; Joshi, C.; Boukherroub, R.; Jain, S.L. Graphene-semiconductor hybrid photocatalysts and their application in solar fuel production. In Advanced 2D Materials; Tiwari, A., Syvãjãrvi, M., Eds.; John Wiley \& Sons: Hoboken, NJ, USA, 2016.

22. Kudo, A.; Miseki, Y. Heterogeneous photocatalyst materials for water splitting. Chem. Soc. Rev. 2009, 38, 253-278. [CrossRef] [PubMed]

23. Jang, J.S.; Kim, H.G.; Lee, J.S. Heterojunction semiconductors: A strategy to develop efficient photocatalytic materials for visible light water splitting. Catal. Today 2012, 185, 270-277. [CrossRef]

24. Ge, M.; Cai, J.; Iocozzia, J.; Cao, C.; Huang, J.; Zhang, X.; Shen, J.; Wang, S.; Zhang, S.; Zhang, K.Q.; et al. A review of $\mathrm{TiO}_{2}$ nanostructured catalysts for sustainable $\mathrm{H}_{2}$ generation. Int. J. Hydrogen Energy 2017, 42, 8418-8449. [CrossRef]

25. Wu, F.; Hu, X.; Fan, J.; Liu, E.; Sun, T.; Kang, L.; Hou, W.; Zhu, C.; Liu, H. Photocatalytic Activity of Ag/TiO 2 nanotube arrays enhanced by surface plasmon resonance and application in hydrogen evolution by water splitting. Plasmonics 2013, 8, 501-508. [CrossRef]

26. Liu, E.; Kang, L.; Yang, Y.; Sun, T.; Hu, X.; Zhu, C.; Liu, H.; Wang, Q.; Li, X.; Fan, J. Plasmonic Ag deposited $\mathrm{TiO}_{2}$ nano-sheet film for enhanced photocatalytic hydrogen production by water splitting. Nanotechnology 2014, 25, 1-10. [CrossRef] [PubMed] 
27. Silva, C.G.; Juarez, R.; Marino, T.; Molinari, R.; Garcia, H. Influence of excitation wavelength (UV or visible light) on the photocatalytic activity of titania containing gold nanoparticles for the generation of hydrogen or oxygen from water. J. Am. Chem. Soc. 2011, 133, 595-602. [CrossRef] [PubMed]

28. Clarizia, L.; Spasiano, D.; Di Somma, I.; Marotta, R.; Andreozzi, R.; Dionysiou, D.D. Copper modified-TiO 2 catalysts for hydrogen generation through photoreforming of organics. A short review. Int. J. Hydrogen Energy 2014, 39, 16812-16831. [CrossRef]

29. Colon, G. Towards the hydrogen production by photocatalysis. Appl. Catal. A Gen. 2015, 518, 48-59. [CrossRef]

30. Chiarello, G.L.; Dozzi, M.V.; Selli, E. $\mathrm{TiO}_{2}$-based materials for photocatalytic hydrogen production. J. Energy Chem. 2017, 26, 250-258. [CrossRef]

31. Yu, J.; Qi, L.; Jaroniec, M. Hydrogen production by photocatalytic water splitting over $\mathrm{Pt} / \mathrm{TiO}_{2}$ nanosheets with exposed (001) facets. J. Phys. Chem. C 2010, 114, 13118-13125. [CrossRef]

32. Li, Q.Y.; Zhao, Z.Y. Interfacial properties of $\alpha / \beta-\mathrm{Bi}_{2} \mathrm{O}_{3}$ homo-junction from first-principles calculations. Phys. Lett. A 2015, 379, 2766-2771. [CrossRef]

33. Melvin, A.A.; Illath, K.; Das, T.; Raja, T.; Bhattacharyya, S.; Gopinath, C.S. M-Au/TiO 2 (M = Ag, Pd, and $\mathrm{Pt})$ nanophotocatalyst for overall solar water splitting: Role of interfaces. Nanoscale 2015, 7, 13477-13488. [CrossRef] [PubMed]

34. Park, J.Y.; Renzas, J.R.; Hsu, B.B.; Somorjai, G.A. Interfacial and chemical properties of $\mathrm{Pt} / \mathrm{TiO}_{2}, \mathrm{Pd} / \mathrm{TiO}_{2}$, and Pt/GaN catalytic nanodiodes influencing hot electron flow. J. Phys. Chem. C 2007, 111, 15331-15336. [CrossRef]

35. Subramanian, V.; Wolf, E.E.; Kamat, P. Catalysis with $\mathrm{TiO}_{2}$ /gold nanocomposites: Effect of metal particle size on the Fermi level equilibration. J. Am. Chem. Soc. 2004, 126, 4943-4950. [CrossRef] [PubMed]

36. Zhou, X.; Liu, G.; Yu, J.; Fan, W. Surface plasmon resonance-mediated photocatalysis by noble metal-based composites under visible light. J. Mater. Chem. 2012, 22, 21337-21354. [CrossRef]

37. Chen, J.J.; $\mathrm{Wu}$, J.C.S.; $\mathrm{Wu}$, P.C.; Tsai, D.P. Plasmonicphotocatalyst for $\mathrm{H}_{2}$ evolution in photocatalytic water splitting. J. Phys. Chem. C 2011, 115, 210-216. [CrossRef]

38. Zhang, X.; Chen, Y.L.; Liu, R.S.; Tsai, D.P. Plasmonic photocatalysis. Rep.Prog. Phys. 2013, 76, 046401. [CrossRef] [PubMed]

39. Warren, S.C.; Thimsen, E. Plasmonic solar water splitting. Energy Environ. Sci. 2012, 5, 5133-5146. [CrossRef]

40. Kitano, M.; Tsujimaru, K.; Anpo, M. Hydrogen production using highly active titanium oxide-based photocatalysts. Top. Catal. 2008, 49, 4-17. [CrossRef]

41. Bazzo, A.; Urakawa, A. Understanding synergetic effects of $\mathrm{Zn}$ and Rh-Cr promotion to wide-bandgap Ga, Ta and Ti oxides in photocatalytic water splitting. Catal. Sci. Technol. 2016, 6, 4243-4253. [CrossRef]

42. Kim, H.G.; Hwang, D.W.; Lee, J.S. An undoped, single-phase oxide photocatalyst working under visible light. J. Am. Chem. Soc. 2004, 126, 8912-8913. [CrossRef] [PubMed]

43. Hara, S.; Yoshimizu, M.; Tanigawa, S.; Ni, L.; Ohtani, B.; Irie, H. Hydrogen and oxygen evolution photocatalysts synthesized from strontium titanate by controlled doping and their performance in two-step overall water splitting under visible light. J. Phys. Chem. C 2012, 116, 17458-17463. [CrossRef]

44. Wang, Q.; Hisatomi, T.; Ma, S.S.K.; Li, Y.; Domen, K. Core/shell structured La- and Rh-codoped $\mathrm{SrTiO}_{3}$ as a hydrogen evolution photocatalyst in Z-scheme overall water splitting under visible light irradiation. Chem. Mater. 2014, 26, 4144-4150. [CrossRef]

45. Primo, A.; Marino, T.; Corma, A.; Molinari, R.; Garcia, H. Efficient visible-light photocatalytic water splitting by minute amounts of gold supported on nanoparticulate $\mathrm{CeO}_{2}$ obtained by a biopolymer templating method. J. Am. Chem. Soc. 2012, 133, 6930-6933. [CrossRef] [PubMed]

46. Wang, Q.; Hisatomi, T.; Jia, Q.; Tokudome, H.; Zhong, M.; Wang, C.; Pan, Z.; Takata, T.; Nakabayashi, M.; Shibata, N.; et al. Scalable water splitting on particulate photocatalyst sheets with a solar-to-hydrogen energy conversion efficiency exceeding 1\%. Nat. Mater. 2016, 15, 611-615. [CrossRef] [PubMed]

47. Liao, L.; Zhang, Q.; Su, Z.; Zhao, Z.; Wang, Y.; Li, Y.; Lu, X.; Wei, D.; Feng, G.; Yu, Q.; et al. Efficient solar water-splitting using a nanocrystalline CoO photocatalyst. Nat. Nanotechnol. 2014, 9, 69-73. [CrossRef] [PubMed]

48. Xu, Y.; Huang, Y.; Zhang, B. Rational design of semiconductor-based photocatalysts for advanced photocatalytic hydrogen production: The case of cadmium chalcogenides. Inorg. Chem. Front. 2016, 3, 591-615. [CrossRef] 
49. Sun, B.; Vorontsov, A.V.; Smirniotis, P.G. Role of platinum deposited on $\mathrm{TiO}_{2}$ in phenol photocatalytic oxidation. J. Phys. Chem. B 2003, 19, 3151-3156.

50. Scanlon, D.O.; Dunnill, C.W.; Buckeridge, J.; Shevlin, S.A.; Logsdail, A.J.; Woodley, S.M.; Catlow, C.R.A.; Powell, M.J.; Palgrave, R.G.; Parkin, I.P.; et al. Band alignment of rutile and anatase $\mathrm{TiO}_{2}$. Nat. Mater. 2013, 12, 798-801. [CrossRef] [PubMed]

51. Mi, Y.; Weng, Y. Band alignment and controllable electron migration between rutile and anatase $\mathrm{TiO}_{2}$. Sci. Rep . 2015, 5, 11482. [CrossRef] [PubMed]

52. Deak, P.; Aradi, B.; Frauenheim, T. Band lineup and charge carrier separation in mixed rutile-anatase systems. J. Phys. Chem. C 2011, 115, 3443-3446. [CrossRef]

53. Zhao, W.N.; Zhu, S.C.; Li, Y.F.; Liu, Z.P. Three-phase junction for modulating electron-hole migration in anatase-rutile photocatalysts. Chem. Sci. 2015, 6, 3483-3494. [CrossRef]

54. Wang, X.; Xu, Q.; Li, M.R.; Shen, S.; Wang, X.L.; Wang, Y.C.; Feng, Z.C.; Shi, Y.J.; Han, H.X.; Li, C. Photocatalytic overall water splitting promoted by an $\alpha-\beta$ phase junction on $\mathrm{Ga}_{2} \mathrm{O}_{3}$. Angew. Chem. Int. Ed. 2012, 51, 13089-13092. [CrossRef] [PubMed]

55. Wang, P.; Chen, P.R.; Kostka, A.; Marschall, R.; Wark, M. Control of phase coexistence in calcium tantalate composite photocatalysts for highly efficient hydrogen production. Chem. Mater. 2013, 25, 4739-4745. [CrossRef]

56. Wang, H.; Zhang, L.; Chen, Z.; Hu, J.; Li, S.; Wang, Z.; Liu, J.; Wang, X. Semiconductor heterojunction photocatalysts: Design, construction, and photocatalytic performances. Chem. Soc. Rev. 2014, 43, 5234-5244. [CrossRef] [PubMed]

57. Ishchenko, O.M.; Rogé, V.; Lamblin, G.; Lenoble, D. $\mathrm{TiO}_{2}$ - and $\mathrm{ZnO}$-Based Materials for Photocatalysis: Material Properties, Device Architecture and Emerging Concepts. Semiconductor PhotocatalysisMaterials, Mechanisms and Applications. Wenbin, Cao, Ed.; InTechOpen, 2016. Available online: https: / / www.intechopen.com/books/semiconductor-photocatalysis-materials-mechanisms-and-applications / tio2-and-zno-based-materials-for-photocatalysis-material-properties-device-architecture-and-emerging (accessed on 13 October 2017).

58. Maeda, K. Z-scheme water splitting using two different semiconductor photocatalysts. ACS Catal. 2013, 3, 1486-1503. [CrossRef]

59. Ibhadon, A.O.; Fitzpatrick, P. Heterogeneous photocatalysis: Recent advances and applications. Catalysts 2013, 3, 189-218. [CrossRef]

60. Ola, O.; Maroto-Valer, M.M. Synthesis, characterization and visible light photocatalytic activity of metal based $\mathrm{TiO}_{2}$ monoliths for $\mathrm{CO}_{2}$ reduction. Chem. Eng. J. 2016, 283, 1244-1253. [CrossRef]

61. Low, J.; Cheng, B.; Yu, J. Surface modification and enhanced photocatalytic $\mathrm{CO}_{2}$ reduction performance of $\mathrm{TiO}_{2}$ : A review. Appl. Surf. Sci. 2017, 392, 658-686. [CrossRef]

62. Pelaez, M.; Nolan, N.T.; Pillai, S.C.; Seery, M.K.; Falaras, P.; Kontos, A.G.; Dunlop, P.S.M.; Hamilton, J.W.J.; Byrne, J.A.; O'Shea, K.; et al. A review on the visible light active titanium dioxide photocatalysts for environmental applications. Appl. Catal. B Environ. 2012, 125, 331-349. [CrossRef]

63. Chen, X.; Mao, S.S. Titanium dioxide nanomaterials: Synthesis, properties, modifications, and applications. Chem. Rev. 2007, 107, 2891-2959. [CrossRef] [PubMed]

64. Zielinska-Jurek, A. Progress, challenge, and perspective of bimetallic $\mathrm{TiO}_{2}$-Based photocatalysts. J. Nanomater. 2014, 1-17. [CrossRef]

65. Jafari, T.; Moharreri, E.; Amin, A.S.; Miao, R.; Song, W.; Suib, S.L. Photocatalytic water splitting-The untamed dream: A review of recent advances. Molecules 2016, 21, 900-929. [CrossRef] [PubMed]

66. Abe, R.; Sayama, K.; Domen, K.; Arakawa, H. A new type of water splitting system composed of two different $\mathrm{TiO}_{2}$ photocatalysts (anatase, rutile) and a $\mathrm{IO}_{3}^{-} / I^{-}$shuttle redox mediator. Chem. Phys. Lett. 2001, 344, 339-344. [CrossRef]

67. Kudo, A. Development of photocatalyst materials forwater splitting. Int. J. Hydrogen Energy 2006, 31, 197-202. [CrossRef]

68. Zhou, H.; Pan, J.; Ding, L.; Tang, Y.; Ding, J.; Guo, Q.; Fan, T.; Zhang, D. Biomass-derived hierarchical porous $\mathrm{CdS} / \mathrm{M} / \mathrm{TiO}_{2}(\mathrm{M}=\mathrm{Au}, \mathrm{Ag}, \mathrm{pt}, \mathrm{pd})$ ternary heterojunctions for photocatalytic hydrogen evolution. Int. J. Hydrogen Energy 2014, 39, 16293-16301. [CrossRef] 
69. Chen, Y.; Zhao, S.; Wang, X.; Peng, Q.; Lin, R.; Wang, Y.; Shen, R.; Cao, X.; Zhang, L.; Zhou, G.; et al. Synergetic integration of $\mathrm{Cu}_{1.94} \mathrm{~S}-\mathrm{Zn}_{\mathrm{x}} \mathrm{Cd}_{1-\mathrm{x}} \mathrm{S}$ heteronanorods for enhanced visible-light-driven photocatalytic hydrogen production. J. Am. Chem. Soc. 2016, 138, 4286-4289. [CrossRef] [PubMed]

70. Jiang, D.; Sun, Z.; Jia, H.; Lu, D.; Du, P. A cocatalyst-free CdS nanorod/ZnS nanoparticle composite for high-performance visible-light-driven hydrogen production from water. J. Mater. Chem. A Mater. Energy Sustain. 2016, 4, 675-683. [CrossRef]

71. Tang, M.L.; Grauer, D.C.; Lassalle-Kaiser, B.; Yachandra, V.K.; Amirav, L.; Yano, J.; Long, J.R.; Alivisatos, A.P. Structural and electronic study of an amorphous $\mathrm{MoS}_{3}$ hydrogen-generation catalyst on a quantum-controlled photosensitizer. Angew. Chem. Int. Ed. 2011, 50, 10203-10207. [CrossRef] [PubMed]

72. Liang, Y.; Zhai, L.; Zhao, X.; Xu, D. Band-Gap engineering of semiconductor nanowires through composition modulation. J. Phys. Chem. B 2005, 109, 7120-7123. [CrossRef] [PubMed]

73. Yuan, Y.J.; Chen, D.Q.; Huang, Y.W.; Yu, Z.T.; Zhong, J.S.; Chen, T.T.; Tu, W.G.; Guan, Z.J.; Cao, D.P.; Zou, Z.G. $\mathrm{MoS}_{2}$ nanosheet-modified $\mathrm{CuInS}_{2}$ photocatalyst for visible-light-driven hydrogen production from water. ChemSusChem 2016, 9, 1003-1009. [CrossRef] [PubMed]

74. Dubale, A.A.; Pan, C.J.; Tamirat, A.G.; Chen, H.M.; Su, W.N.; Chen, C.H.; Rick, J.; Ayele, D.W.; Aragaw, B.A.; Lee, J.F.; et al. Heterostructured $\mathrm{Cu}_{2} \mathrm{O} / \mathrm{CuO}$ decorated with nickel as a highly efficient photocathode for photoelectrochemical water reduction. J. Mater. Chem. A 2015, 3, 12482-12499. [CrossRef]

75. Sun, Z.; Chen, H.; Zhang, L.; Lu, D.; Du, P. Enhanced photocatalytic $\mathrm{H}_{2}$ production on cadmium sulfide photocatalysts using nickel nitride as a novel cocatalyst. J. Mater. Chemistry A 2016, 4, 13289-13295. [CrossRef]

76. Maeda, K.; Lu, D.; Domen, K. Solar-driven Z-scheme water splitting using modified BaZrO3-BaTaO2N solid solutions as photocatalysts. ACS Catal. 2013, 3, 1026-1033. [CrossRef]

77. Ma, S.S.K.; Maeda, K.; Hisatomi, T.; Tabata, M.; Kudo, A.; Domen, K. A redox-mediator-free solar-driven Z-scheme water-splitting system consisting of modified $\mathrm{Ta}_{3} \mathrm{~N}_{5}$ as an oxygen-evolution photocatalyst. Chem. A Eur. J. 2013, 19, 7480-7486. [CrossRef] [PubMed]

78. Matoba, T.; Maeda, K.; Domen, K. Activation of $\mathrm{BaTaO}_{2} \mathrm{~N}$ photocatalyst for enhanced non-sacrificial hydrogen evolution from water under visible light by forming a solid solution with $\mathrm{BaZrO}_{3}$. Chem. A Eur. J. 2011, 17, 14731-14735. [CrossRef] [PubMed]

79. Sasaki, Y.; Nemoto, H.; Saito, K.; Kudo, A. Solar water splitting using powdered photocatalysts driven by Z-schematic interparticle electron transfer without an electron mediator. J. Phys. Chem. C 2009, 113, 17536-17542. [CrossRef]

80. Pihosh, Y.; Turkevych, I.; Mawatari, K.; Uemura, J.; Kazoe, Y.; Kosar, S.; Makita, K.; Sugaya, T.; Matsui, T.; Fujita, D.; et al. Photocatalytic generation of hydrogen by core-shell $\mathrm{WO}_{3} / \mathrm{BiVO}_{4}$ nanorods with ultimate water splitting efficiency. Sci. Rep. 2015, 5, 11141-11151. [CrossRef] [PubMed]

81. Wang, X.Y.; Yin, L.C.; Liu, G. Light irradiation-assisted synthesis of ZnO-CdS/reduced graphene oxide heterostructured sheets for efficient photocatalytic $\mathrm{H}_{2}$ evolution. Chem. Commun. 2014, 50, 3460-3463. [CrossRef] [PubMed]

82. Hou, J.G.; Wang, Z.; Kan, W.B.; Jiao, S.Q.; Zhu, H.M.; Kumar, R.V. Efficient visible-light-driven photocatalytic hydrogen production using CdS@TaON core-shell composites coupled with graphene oxide nanosheets. J. Mater. Chem. 2012, 22, 7291-7299. [CrossRef]

83. Chen, X.; Shen, S.; Guo, L.; Mao, S.S. Semiconductor-based photocatalytic hydrogen generation. Chem. Rev. 2010, 110, 6503-6570. [CrossRef] [PubMed]

84. Navarro, R.M.; del Valle, F.; Villoria de la Mano, J.A.; Alvarez-Galvan, M.C.; Fierro, J.L.G. Photocatalytic water splitting under visible light: Concept and catalysts development. Adv. Chem. Eng. Prog. Photocatal. React. Eng. 2009, 36, 111-143.

85. Luque, R.; Balu, A.M. Producing Fuels and Fine Chemicals from Biomass Using Nanomaterials; CRC Press, Taylor \& Francis Group: Boca Raton, FL, USA, 2013.

86. Takata, T.; Domen, K. Defect engineering of photocatalysts by doping of aliovalent metal cations for efficient water splitting. J. Phys. Chem. C 2009, 45, 19386-19388. [CrossRef]

87. Boumaza, S.; Boudjemaa, A.; Bouguelia, A.; Bouarab, R.; Trari, M. Visible light induced hydrogen evolution on new hetero-system $\mathrm{ZnFe}_{2} \mathrm{O}_{4} / \mathrm{SrTiO}_{3}$. Appl. Energy 2010, 87, 2230-2236. [CrossRef]

88. Li, Y.; Chen, G.; Wang, Q.; Wang, X.; Zhou, A.; Shen, Z. Hierarchical ZnS-In ${ }_{2} \mathrm{~S}_{3}-\mathrm{CuS}$ nanospheres with nanoporous structure: Facile synthesis, growth mechanism, and excellent photocatalytic activity. Adv. Funct. Mater. 2010, 20, 3390-3398. [CrossRef] 
89. Bamwenda, G.R.; Arakawa, H. The photoinduced evolution of suspension $\mathrm{O}_{2}$ and $\mathrm{H}_{2}$ from a $\mathrm{WO}_{3}$ aqueous suspension in the presence of $\mathrm{Ce}^{4+} / \mathrm{Ce}^{3+}$. Sol. Energy Mater. Sol. Cells 2001, 70, 1-14. [CrossRef]

90. Koca, A.; Sahin, M. Photocatalytic hydrogen production by direct sun light from sulfide/sulfite solution. Int. J. Hydrogen Energy 2002, 27, 363-367. [CrossRef]

91. Lee, K.; Nam, W.S.; Han, G.Y. Photocatalytic water-splitting in alkaline solution using redox mediator. 1:Parameter study. Int. J. Hydrogen Energy 2004, 29, 1343-1347. [CrossRef]

92. Ni, M.; Leung, M.K.H.; Leung, D.Y.C.; Sumathy, K. A review and recent developments in photocatalytic water-splitting using $\mathrm{TiO}_{2}$ for hydrogen production. Renew. Sustain. Energy Rev. 2007, 11, 401-425. [CrossRef]

93. Tee, S.Y.; Win, K.Y.; Teo, W.S.; Koh, L.D.; Liu, S.; Teng, C.P.; Han, M.Y. Recent progress in energy-driven water splitting. Adv. Sci. 2017, 4, 1600337. [CrossRef] [PubMed]

94. Liao, C.H.; Huang, C.W.; Wu, J.C.S. Hydrogen production from semiconductor-based photocatalysis via water splitting. Catalysts 2012, 2, 490-516. [CrossRef]

95. Kim, J.; Hwang, D.W.; Kim, H.G.; Bae, S.W.; Lee, J.S.; Li, W.; Oh, S.H. Highly efficient overall water splitting through optimization of preparation and operation conditions of layered perovskite photocatalysts. Top. Catal. 2005, 35, 295-303. [CrossRef]

96. Kato, H.; Asakura, K.; Kudo, A. Highly efficient water splitting into $\mathrm{H}_{2}$ and $\mathrm{O}_{2}$ over lanthanum-doped $\mathrm{NaTaO}_{3}$ photocatalysts with high crystallinity and surface nanostructure. J. Am. Chem. Soc. 2003, 125, 3082-3089. [CrossRef] [PubMed]

97. Jing, D.; Guo, L.; Zhao, L.; Zhang, X.; Liu, H.; Li, M.; Shen, S.; Liu, G.; Hu, X.; Zhang, X.; et al. Efficient solar hydrogen production by photocatalytic water splitting: From fundamental study to pilot demonstration. Int. J. Hydrogen Energy 2010, 35, 7087-7097. [CrossRef]

98. Turner, J.; Sverdrup, G.; Mann, M.K.; Maness, P.C.; Kroposki, B.; Ghirardi, M.; Evans, R.J.; Blake, D. Renewable hydrogen production. Int. J. Energy Res. 2007, 32, 379-407. [CrossRef]

99. Bowker, M. Photocatalytic hydrogen production and oxygenate photoreforming. Catal. Lett. 2012, 142, 923-929. [CrossRef]

100. Yasuda, M.; Matsumoto, T.; Yamashita, T. Sacrificial hydrogen production over TiO2-based photocatalysts: Polyols, carboxylic acids, and saccharides. Renew. Sustain. Energy Rev. 2017, in press. [CrossRef]

101. Colmenares, J.C.; Luque, R. Heterogeneous photocatalytic nanomaterials: Prospects and challenges in selective transformations of biomass-derived compounds. Chem. Soc. Rev. 2014, 43, 765-778. [CrossRef] [PubMed]

102. Colmenares, J.C.; Magdziarz, A.; Aramendia, M.A.; Marinas, A.; Marinas, J.M.; Urbano, F.J.; Navio, J.A. Influence of the strong metal support interaction effect (SMSI) of $\mathrm{Pt} / \mathrm{TiO}_{2}$ and $\mathrm{Pd} / \mathrm{TiO}_{2}$ systems in the photocatalytic biohydrogen production from glucose solution. Catal. Commun. 2011, 16, 1-6. [CrossRef]

103. Ilie, M.; Cojocaru, B.; Parvulescu, V.I.; Garcia, H. Improving $\mathrm{TiO}_{2}$ activity in photo-production of hydrogen from sugar industry wastewaters. Int. J. Hydrogen Energy 2011, 36, 15509-15518. [CrossRef]

104. Pilkenton, S.; Hwang, S.J.; Raftery, D. Ethanol photocatalysis on $\mathrm{TiO}_{2}$-coated optical microfiber, supported monolayer, and powdered catalysts: An in situ NMR study. J. Phys. Chem. B 1999, 103, 11152-11160. [CrossRef]

105. Xu, W.; Raftery, D. Photocatalytic oxidation of 2-propanol on $\mathrm{TiO}_{2}$ powder and $\mathrm{TiO}_{2}$ monolayer catalysts studied by solid-state NMR. J. Phys. Chem. B 2001, 105, 4343-4349. [CrossRef]

106. Fu, X.; Wang, X.; Leung, D.Y.C.; Gu, Q.; Chen, S.; Huang, H. Photocatalytic reforming of $\mathrm{C}_{3}$-polyols for $\mathrm{H}_{2}$ production: Part (I). Role of their OH groups.Appl. Catal. B 2011, 106, 681-688. [CrossRef]

107. Wang, C.Y.; Rabani, J.; Bahnemann, D.W.; Dohrmann, J.K. Photonic efficiency and quantum yield of formaldehyde formation from methanol in the presence of various $\mathrm{TiO}_{2}$ photocatalysts. J. Photochem. Photobiol. A 2002, 148, 169-176. [CrossRef]

108. Du, M.; Feng, J.; Zhang, S.B. Photo-oxidation of polyhydroxyl molecules on $\mathrm{TiO}_{2}$ surfaces: From hole scavenging to light-induced self-assembly of $\mathrm{TiO}_{2}$-cyclodextrin wires. Phys. Rev. Lett. 2007, 98, 1-4. [CrossRef] [PubMed]

109. Fu, X.; Long, J.; Wang, X.; Leung, D.Y.C.; Ding, Z.; Wu, L.; Zhang, Z.; Li, Z.; Fu, X. Photocatalytic reforming of biomass: A systematic study of hydrogen evolution from glucose solution. Int. J. Hydrogen Energy 2008, 33, 6484-6491. [CrossRef]

110. Balducci, G. The adsorption of glucose at the surface of anatase: A computational study. Chem. Phys. Lett. 2010, 494, 54-59. [CrossRef] 
111. Jia, L.; Li, J.; Fang, W. Effect of $\mathrm{H}_{2} / \mathrm{CO}_{2}$ mixture gas treatment temperature on the activity of $\mathrm{LaNiO}_{3}$ catalyst for hydrogen production from formaldehyde aqueous solution under visible light. J. Alloy. Compd. 2010, 489, L13-L16. [CrossRef]

112. Patsoura, A.; Kondarides, D.I.; Verykios, X.E. Photocatalytic degradation of organic pollutants with simultaneous production of hydrogen. Catal. Today 2007, 124, 94-102. [CrossRef]

113. Shen, S.; Guo, L. Hydrothermal synthesis, characterization, and photocatalytic performances of $\mathrm{Cr}$ incorporated, and $\mathrm{Cr}$ and Ti co-incorporated MCM-41 as visible light photocatalysts for water splitting. Catal. Today 2007, 129, 414-420. [CrossRef]

114. Zheng, X.J.; Wei, L.F.; Zhang, Z.H.; Jiang, Q.J.; Wei, Y.J.; Xie, B.; Wei, M.B. Research on photocatalytic $\mathrm{H}_{2}$ production from acetic acid solution by $\mathrm{Pt} / \mathrm{TiO}_{2}$ nanoparticles under UV irradiation. Int. J. Hydrogen Energy 2009, 34, 9033-9041. [CrossRef]

115. Caravaca, A.; Jones, W.; Hardacre, C.; Bowker, M. $\mathrm{H}_{2}$ production by the photocatalytic reforming of cellulose and raw biomass using Ni, Pd, Pt and Au on titania. Proc. R. Soc. 2016, 472, 20160054. [CrossRef] [PubMed]

116. Patsoura, A.; Kondarides, D.I.; Verykios, X.E. Enhancement of photoinduced hydrogen production from irradiated $\mathrm{Pt} / \mathrm{TiO}_{2}$ suspensions with simultaneous degradation of azodyes. Appl. Catal. B 2006, 64, 171-179. [CrossRef]

117. Sakata, T.; Kawai, T.; Hashimoto, K. Heterogeneous photocatalytic reactions of organic acids and water. New reaction paths besides the photo-Kolbe reaction. J. Phys. Chem. 1984, 88, 2344-2350. [CrossRef]

118. Al-Azri, Z.H.N.; Chen, W.T.; Chan, A.; Jovic, V.; Ina, T.; Idriss, H.; Waterhouse, G.I.N. The roles of metal co-catalysts and reaction media in photocatalytic hydrogen production: Performance evaluation of $\mathrm{M} / \mathrm{TiO}_{2}$ photocatalysts (M=Pd, Pt, Au) in different alcohol-water mixtures. J. Catal. 2015, 329, 355-367. [CrossRef]

119. Sadanandam, G.; Lalitha, K.; Kumari, V.D.; Shankar, M.V.; Subrahmanyam, M. Cobalt doped $\mathrm{TiO}_{2}$ : A stable and efficient photocatalyst for continuous hydrogen production from glycerol: Water mixtures under solar light irradiation. Int. J. Hydrogen Energy 2013, 38, 9655-9664. [CrossRef]

120. Jing, D.; Zhang, Y.; Guo, L. Study on the synthesis of Ni doped mesoporous $\mathrm{TiO}_{2}$ and its photocatalytic activity for hydrogen evolution in aqueous methanol solution. Chem. Phys. Lett. 2005, 415, 74-78. [CrossRef]

121. Clarizia, L.; Vitiello, G.; Luciani, G.; Di Somma, I.; Andreozzi, R.; Marotta, R. In-situ photodeposited nanoCu on $\mathrm{TiO}_{2}$ as a catalyst for hydrogen production under UV/visible radiation. Appl. Catal. A Gen. 2016, 518, 142-149. [CrossRef]

122. Clarizia, L.; Di Somma, I.; Marotta, R.; Minutolo, P.; Villamaina, R.; Andreozzi, R. Photocatalytic reforming of formic acid for hydrogen production in aqueous solutions containing cupric ions and $\mathrm{TiO}_{2}$ suspended nanoparticles under UV-simulated solar radiation. Appl. Catal. A Gen. 2016, 518, 181-188. [CrossRef]

123. Lucchetti, R.; Onotri, L.; Clarizia, L.; Di Natale, F.; Di Somma, I.; Andreozzi, R.; Marotta, R. Removal of nitrate and simultaneous hydrogen generation through photocatalytic reforming of glycerol over "in situ" prepared zero-valent nano copper/P25. Appl. Catal. B Environ. 2017, 202, 539-549. [CrossRef]

124. Kondarides, D.I.; Daskalaki, V.M.; Patsoura, A.; Verykios, X.E. Hydrogen production by photo-induced reforming of biomass components and derivatives at ambient conditions. Catal.Lett. 2008, 122, 26-32. [CrossRef]

125. Gholipour, M.R.; Dinh, C.T.; Béland, F; Do, T.O. Nanocomposite heterojunctions as sunlight-drivenphotocatalysts for hydrogen production from water splitting. Nanoscale 2015, 7, 8187-8208. [CrossRef] [PubMed]

126. Domen, K.; Kondo, J.N.; Hara, M.; Takata, T. Photo- and mechano-catalytic overall water splitting reactions to form hydrogen and oxygen on heterogeneous catalysts. Bull. Chem. Soc. Jpn. 2000, 73, 1307-1331. [CrossRef]

127. Li, Y.; Chen, G.; Zhang, H.; Li, Z.; Sun, J. Electronic structure and photocatalytic properties of $\mathrm{ABi}_{2} \mathrm{Ta}_{2} \mathrm{O}_{9}$ (A=Ca, Sr, Ba). J. Solid State Chem. 2008, 181, 2653-2659. [CrossRef]

128. Simon, T.; Bouchonville, N.; Berr, M.J.; Vaneski, A.R.; Adrović, A.; Volbers, D.; Wyrwich, R.; Döblinger, M.; Susha, A.S.; Rogach, A.L.; et al. Redox shuttle mechanism enhances photocatalytic $\mathrm{H}_{2}$ generation on Ni-decorated CdS nanorods. Nat. Mater. 2014, 13, 1013-1018. [CrossRef] [PubMed]

129. Li, Q.; Guo, B.; Yu, J.; Ran, J.; Zhang, B.; Yan, H.; Gong, J.R. Highly efficient visible-light-driven photocatalytic hydrogen production of CdS-cluster-decorated graphene nanosheets. J. Am. Chem. Soc. 2011, 133, 10878-10884. [CrossRef] [PubMed]

130. Amirav, L.; Alivisatos, A.P. Photocatalytic hydrogen production with tunable nanorod heterostructures. J. Phys. Chem. Lett. 2010, 1, 1051-1054. [CrossRef] 
131. Parida, K.M.; Martha, S.; Das, D.P.; Biswal, N. Facile fabrication of hierarchical N-doped GaZn mixed oxides for water splitting reactions. J. Mater. Chem. 2010, 20, 7144-7149. [CrossRef]

132. Fontelles-Carceller, O.; Muñoz-Batista, M.J.; Rodríguez-Castellón, E.; Conesa, J.C.; Fernández-García, M.; Kubacka, A. Measuring and interpreting quantum efficiency for hydrogen photoproduction using Pt-titania catalysts. J. Catal. 2017, 347, 157-169. [CrossRef]

133. Meshram, S.P.; Adhayak, P.V.; Mulik, U.P.; Amalnerkar, D.P. Facile synthesis of CuO nanomorphs and their morphology dependent sunlight driven photocatalytic properties. Chem. Eng. J. 2012, 204-206, 158-168. [CrossRef]

134. Zhang, Z.; Maggard, P.A. Investigation of photocatalytically-active hydrated forms of amorphous titania, $\mathrm{TiO}_{2} \cdot n \mathrm{H}_{2} \mathrm{O}$. J. Photochem. Photobiol. A Chem. 2007, 186, 8-13. [CrossRef]

135. Zhang, Z.; Wang, C.C.; Zakaria, R.; Ying, J.Y. Role of particle size in nanocrystalline $\mathrm{TiO}_{2}$-based photocatalysts. J. Phys. Chem. B 1998, 102, 10871-10878. [CrossRef]

136. Muller, U. Symmetry. In Inorganic Structural Chemistry; John Wiley and Sons, Ltd.: Chichester, UK, 2007.

137. Tan, Y.N.; Wong, C.L.; Mohamed, A.R. An overview on the photocatalytic activity of nano-doped-TiO $\mathrm{T}_{2}$ in the degradation of organic pollutants. ISRN Mater. Sci. 2011, 2011, 1-18. [CrossRef]

138. Ola, O.; Maroto-Valer, M.M. Review of material design and reactor engineering on $\mathrm{TiO}_{2}$ photocatalysis for $\mathrm{CO}_{2}$ reduction. J. Photochem. Photobiol. C Photochem. Rev. 2015, 24, 16-42. [CrossRef]

139. Osterloh, F.E. Nanoscale effects in water splitting photocatalysis. Top. Curr. Chem. 2015, 371, $105-142$.

140. Olshansky, J.H.; Ding, T.X.; Lee, Y.V.; Leone, S.R.; Alivisatos, A.P. Hole transfer from photoexcited quantum dots: The relationship between driving force and rate. J. Am. Chem. Soc. 2015, 137, 15567-15575. [CrossRef] [PubMed]

141. Sachs, M.; Pastor, E.; Kafizas, A.; Durrant, J.R. Evaluation of surface state mediated charge recombination in anatase and rutile $\mathrm{TiO}_{2}$. J. Phys. Chem. Lett. 2016, 7, 3742-3746. [CrossRef] [PubMed]

142. Mijoe, J. Fundamentals of Semiconductor Physics; Anchor Academic Publishing: Hamburg, Germany, 2015.

143. Kim, W.D.; Kim, J.H.; Lee, S.; Lee, S.; Woo, J.Y.; Lee, K.; Chae, W.S.; Jeong, S.; Bae, W.K.; McGuire, J.A.; et al. Role of surface states in photocatalysis: Study of chlorine-passivated CdSe nanocrystals for photocatalytic hydrogen generation. Chem. Mater. 2016, 28, 962-968. [CrossRef]

144. Sreethawong, T.; Yoshikawa, S. Comparative investigation on photocatalytic hydrogen evolution over $\mathrm{Cu}-$, $\mathrm{Pd}-$, and $\mathrm{Au}$-loaded mesoporous $\mathrm{TiO}_{2}$ photocatalysts. Catal. Commun. 2005, 6, 661-665. [CrossRef]

145. Peng, Q.; Xiong, R.; Sa, B.; Zhou, J.; Wen, C.; Wu, B.; Anpo, M.; Sun, Z. Computational mining of photocatalysts for water splitting hydrogen production: Two-dimensional InSe-family monolayers. Catal. Sci. Technol. 2017, 7, 2744-2752. [CrossRef]

146. Du, Y.A.; Chen, Y.W.; Kuo, J.L. First principles studies on the redox ability of $\left(\mathrm{Ga}_{1-x} \mathrm{Zn}_{x}\right) \mathrm{N}_{1-x} \mathrm{O}_{x}$ solid solutions and thermal reactions for $\mathrm{H}_{2}$ and $\mathrm{O}_{2}$ production on their surfaces. Phys. Chem. Chem. Phys. 2013, 15, 19807-19818. [CrossRef] [PubMed]

147. Gurdal, Y.; Iannuzzi, M. DFT-based Theoretical simulations for photocatalytic applications using $\mathrm{TiO}_{2}$. In Titanium Dioxide; Janus, M., Ed.; InTech: Rijeka, Croatia, 2017.

148. Garcia-Esparza, A.T.; Takanabe, K. A simplified theoretical guideline for overall water splitting using photocatalyst particles. J. Mater. Chem. 2016, 4, 2894-2908. [CrossRef]

149. Liu, G.; Zhang, X.; Xu, Y.; Niu, X.; Zheng, L.; Ding, X. The preparation of $\mathrm{Zn}^{2+}$-doped $\mathrm{TiO}_{2}$ nanoparticles by sol-gel and solid phase reaction methods respectively and their photocatalytic activities. Chemosphere 2005, 59, 1367-1371. [CrossRef] [PubMed]

150. Xiao, Q.; Zhang, J.; Xiao, C.; Si, Z.; Tan, X. Solar photocatalytic degradation of methylene blue in carbon-doped $\mathrm{TiO}_{2}$ nanoparticles suspension. Sol. Energy 2008, 82, 706-713. [CrossRef]

151. Hoffmann, M.R.; Martin, S.T.; Choi, W.; Bahnemann, D.W. Environmental applications of semiconductor photocatalysis. Chem. Rev. 1995, 95, 69-96. [CrossRef]

152. Bak, T.; Nowotny, J.; Rekas, M.; Sorrell, C.C. Photo-electrochemical hydrogen generation from water using solar energy. Materials-related aspects. Int. J. Hydrogen Energy 2002, 27, 991-1022. [CrossRef]

153. Spasiano, D.; Marotta, R.; Malato, S.; Fernandez-Ibanez, P.; Di Somma, I. Solar photocatalysis: Materials, reactors, some commercial, and pre-industrialized applications. A comprehensive approach. Appl. Catal. B Environ. 2015, 170, 90-123. [CrossRef]

154. $\mathrm{Xu}, \mathrm{Y}$.; Schoonen, M.A.A. The absolute energy positions of conduction and valence bands of selected semiconducting minerals. Am. Mineral. 2000, 85, 543-556. [CrossRef] 
155. Kosmulski, M. Isoelectric points and points of zero charge of metal (hydr)oxides: 50 years after Parks' review. Adv. Colloid Interface Sci. 2017, in press. [CrossRef] [PubMed]

156. Maeda, K.; Takata, T.; Hara, M.; Saito, N.; Inoue, Y.; Kobayashi, H.; Domen, K. GaN:ZnO solid solution as a photocatalyst for visible-light-driven overall water splitting. J. Am. Chem. Soc. 2005, 127, 8286-8297. [CrossRef] [PubMed]

157. Maeda, K.; Saito, N.; Lu, D.; Inoue, Y.; Domen, K. Photocatalytic properties of $\mathrm{RuO}_{2}$-loaded $\beta$-Ge $\mathrm{N}_{4}$ for overall water splitting. J. Phys. Chem. C 2007, 111, 4749-4755. [CrossRef]

158. Takata, T.; Shinohara, S.; Tanaka, A.; Hara, M.; Kondo, J.N.; Domen, K. A highly active photocatalyst for overall water splitting with a hydrated layered perovskite structure. J. Photochem. Photobiol. A Chem. 1997, 106, 45-49. [CrossRef]

159. Kato, H.; Kudo, A. Water splitting into $\mathrm{H}_{2}$ and $\mathrm{O}_{2}$ on alkali tantalite photocatalysts $\mathrm{ATaO}_{3}(\mathrm{~A}=\mathrm{Li}, \mathrm{Na}$ and $\mathrm{K})$. J. Phys. Chem. B 2001, 105, 4285-4292. [CrossRef]

160. Maeda, K.; Teramura, K.; Masuda, H.; Takata, T.; Saito, N.; Inoue, Y.; Domen, K. Efficient overall water splitting under visible-light irradiation on $\left(\mathrm{Ga}_{1-x} \mathrm{Zn}_{x}\right)\left(\mathrm{N}_{1-x} \mathrm{O}_{x}\right)$ dispersed with $\mathrm{Rh}-\mathrm{Cr}$ mixed-oxide nanoparticles: Effect of reaction conditions on photocatalytic activity. J. Phys. Chem. B 2006, 110, 13107-13112. [CrossRef] [PubMed]

161. Nada, A.A.; Hamed, H.A.; Barakat, M.H.; Mohamed, N.R.; Veziroglu, T.N. Enhancement of photocatalytic hydrogen production rate using photosensitized $\mathrm{TiO}_{2} / \mathrm{RuO}_{2}-\mathrm{MV}^{2+}$. Int. J. Hydrogen Energy 2008, 33, 3264-3269. [CrossRef]

162. Ismail, A.A. MesoporousPdO-TiO 2 nanocomposites with enhanced photocatalytic activity. Appl. Catal. B Environ. 2012, 117-118, 67-72. [CrossRef]

163. Lalitha, K.; Reddy, J.K.; Sharma, M.V.P.; Kumari, V.D.; Subrahmanyam, M. Continuous hydrogen production activity over finely dispersed $\mathrm{Ag}_{2} \mathrm{O} / \mathrm{TiO}_{2}$ catalysts from methanol:water mixture under solar irradiation: A structure-activity correlation. Int. J. Hydrogen Energy 2010, 35, 3991-4001. [CrossRef]

164. Rosseler, O.; Shankar, M.V.; Karkmaz-Le Du, M.; Schmidlin, L.; Keller, N.; Keller, V. Solar light photocatalytic hydrogen production from water over $\mathrm{Pt}$ and $\mathrm{Au} / \mathrm{TiO}_{2}$ (anatase/rutile) photo-catalysts: Influence of noble metal and porogen promotion. J. Catal. 2010, 269, 179-190. [CrossRef]

165. Hisatomi, T.; Maeda, K.; Takanabe, K.; Kubota, J.; Domen, K. Aspects of the water splitting mechanism on $\left(\mathrm{Ga}_{1-\mathrm{x}} \mathrm{Zn}_{\mathrm{x}}\right)\left(\mathrm{N}_{1-\mathrm{x}} \mathrm{O}_{\mathrm{x}}\right)$ photocatalyst modified with $\mathrm{Rh}_{2-\mathrm{y}} \mathrm{Cr}_{\mathrm{y}} \mathrm{O}_{3}$ cocatalyst. J. Phys. Chem. C 2009, 113, 21458-21466. [CrossRef]

166. Hisatomi, T.; Miyazaki, K.; Takanabe, K.; Maeda, K.; Kubota, J.; Sakata, Y.; Domen, K. Isotopic and kinetic assessment of photocatalytic water splitting on $\mathrm{Zn}$-added $\mathrm{Ga}_{2} \mathrm{O}_{3}$ photocatalyst loaded with $\mathrm{Rh}_{2-\mathrm{y}} \mathrm{Cr}_{\mathrm{y}} \mathrm{O}_{3}$ cocatalyst. Chem. Phys. Lett. 2010, 486, 144-146. [CrossRef] 